\title{
Tuning Dunaliella tertiolecta for Enhanced Antioxidant Production by Modification of Culture Conditions
}

\author{
Uttam K. Roy ${ }^{1,2}$ (D) Birthe V. Nielsen ${ }^{2} \cdot$ John J. Milledge ${ }^{2}$
}

Received: 30 June 2020 / Accepted: 30 May 2021 / Published online: 30 June 2021

(c) The Author(s) 2021

\begin{abstract}
Microalgae, a popular source of food and bioactive compounds, accumulate antioxidants in response to culture condition stresses. Using a factorial design $(3 \times 3)$, the effect of light, temperature, and nitrogen level on chlorophyll and carotenoids, total protein, total phenolic, ascorbate and glutathione content, and enzyme (catalase (CAT), superoxide dismutase (SOD), and peroxidase (POD)) activities in Dunaliella tertiolecta was studied. Data were analysed using Design of Experiments (DoE), and recommendations are made for optimum cultivation conditions to achieve the highest antioxidant content (phenolics, ascorbate and glutathione) or enzyme (CAT, SOD, and POD) activities. This is the first study to apply three levels of three factors during cultivation to tune Dunaliella tertiolecta for optimal antioxidant production.
\end{abstract}

Keywords Microalgae $\cdot$ Dunaliella tertiolecta $\cdot$ Culture conditions $\cdot$ Antioxidants $\cdot$ Enzyme activity

\section{Introduction}

Subjected to oxidative stress, Dunaliella accumulates different biomolecules, including antioxidants, and it has been suggested that $D$. salina could be a useful source for enzyme production (Ben-Amotz and Avron 1990; El-Baky et al. 2004). Microalgae can be used as bio-factories for largescale production of cellulase, galactosidases, phytase, lipase amylase, and antioxidant enzymes which are commercially used in food, animal feed, textile, biofuel, and in the chemical industry (Brasil et al. 2017; Georgianna et al. 2013).

Antioxidants accumulate to eliminate oxidative stress, which occurs due to the generation of endogenous reactive oxygen species (ROS) during cell metabolism (photosynthetic reaction or photorespiration) (Gill and Tuteja 2010). Microalgae have developed an antioxidant defence system to alleviate the adverse effect of ROS which is composed

Uttam K. Roy

u.u.roy@lboro.ac.uk

1 School of Architecture, Building and Civil Engineering, Loughborough University, Epinal Way Leicestershire, Loughborough LE11 3TU, United Kingdom

2 Algae Biotechnology Research Group, Faculty of Engineering and Science, University of Greenwich, Central Avenue, Chatham Maritime, Kent ME4 4TB, England, United Kingdom of superoxide dismutase (SOD), catalase (CAT), ascorbate peroxidase (APX), glutathione reductase (GR), monodehydroascorbate reductase (MDHAR), dehydroascorbate reductase (DHAR), and (glutathione peroxidase (GPX) as well as non-enzymatic molecules (ascorbate, glutathione, carotenoid, phenolic, tocopherol, and proline) (Al-Rashed et al. 2016; Ambati et al. 2019; Cirulis et al. 2013; Michalak 2006; Nimse and Pal 2015; Rahal et al. 2014; Şen 2012; Sharma et al. 2012). Research has shown that Dunaliella strains exposed to challenging culture conditions could cause extensive intracellular ROS production, which would enhance antioxidant responses (Benavente-valdes et al. 2016; Juneja et al. 2013). Culture conditions include light or spectral variation of light, nutrient availabilities, temperature, heavy metals, $\mathrm{pH}$, chemical ingredients, and is usually a combination of several of these (Al-Rashed et al. 2016; Haghjou et al. 2009; Janknegt et al. 2009; Lv et al. 2016; Tian and Yu 2009).

Culture conditions, such as light irradiation (intensity, ultraviolet (UV) irradiation, wavelength, colour), variation of temperature, nitrogen levels (starvation or limitation) affect the cell's chloroplastic protein synthesis, the rate of photosynthesis, oxidative phosphorylation in cells, and any interruption of these cellular metabolisms can induce oxidative stress, which is then mitigated by the accumulation of both non-enzymatic and enzymatic antioxidants (Al-Rashed et al. 2016; Haghjou et al. 2009; Haghjou et al. 
2006; Mohsenpour et al. 2012; Orefice et al. 2016; SanchezSaavedra and Voltolina, 2006; Schulze et al. 2016; Shu et al. 2012; Yilancioglu et al. 2014).

Most research on antioxidant enzyme activity in Dunaliella focuses on only one stressor with a few studies assessing the combined effect of two. There is a need for further research into this area to develop a deeper understanding of the 'tuning parameters' for enhanced enzymatic activity. Studies suggest that the combined effect of tuning several culture conditions is more effective for producing antioxidant responses in Dunaliella compared to exposure to a single stressor (Juneja et al. 2013; Al-Rashed et al. 2016; Lv et al. 2016). For instance, D. salina cells grown under UVirradiation together with nitrogen limitation (El-Baky et al. $2004)$ or cells grown at low $\left(13^{\circ} \mathrm{C}\right)$ temperature combined with light irradiation $\left(100 \mu \mathrm{mol}\right.$ photons $\left.\mathrm{m}^{-2} \mathrm{~s}^{-1}\right)$ (Haghjou et al. 2009) showed a higher enzymatic antioxidant activity compared to cells grown in controlled culture conditions. In addition, variation of light irradiation, extremely high or low temperature, high salinity, nutrient concentration (excess or starvation), UV irradiation or combination of culture conditions (low temperature and high light, UV irradiation and nitrogen starvation, high salinity with nitrogen starvation) have all been shown to enhance levels of non-enzymatic antioxidants (carotenoids, ascorbate, glutathione, tocopherol, phenolic) in Dunaliella (Gallego-Cartagena et al. 2019; Gómez and González 2005; Nguyen et al. 2016; Singh et al. 2016; Al-Rashed et al. 2016; Haghjou et al. 2009). Most research has focused on these non-enzymatic antioxidants rather than the enzymatic antioxidants production.

To use Dunaliella for antioxidant enzyme production, the culture conditions must be tuned to optimise the production of these high-value compounds. In this study, D. tertiolecta cells were exposed to three levels of each factor (light irradiation, temperature, nitrogen levels), and the combined effect on antioxidant productions was assessed. Enzymatic antioxidant (CAT, SOD, and peroxidase (POD)) activities and non-enzymatic antioxidant (phenolic, ascorbate, and glutathione) content in cell pellets were determined. To the best of our knowledge, this is the first report that describes the combined effect of light, temperature, and nitrogen level in enhancing enzymatic and non-enzymatic antioxidants production in $D$. tertiolecta.

\section{Materials and Methods}

\section{Microalgae Species and Reagents}

D. tertiolecta (CCAP 19/30) was obtained from the culture collection of Algae and Protozoa (CCAP, Scotland, UK). Modified Lowry assay kit (Lowry reagent and $2 \mathrm{~N}$ FolinCiocalteu reagent) was obtained from Thermo Scientific
(UK), and all other reagents and enzymes were purchased from Sigma-Aldrich (UK).

\section{Factorial Design Experiment}

A factorial experiment was designed to evaluate the effect of culture conditions on antioxidant responses in D. tertiolecta. Three light levels $\left(15,145,550 \mu \mathrm{mol}\right.$ photons $\left.\mathrm{m}^{-2} \mathrm{~s}^{-1}\right)$, three temperatures $\left(10,20,30^{\circ} \mathrm{C}\right)$, and three different nitrogen levels $\left(0.05,0.5,5 \mathrm{mM} \mathrm{KNO}_{3}\right)$ were chosen as cultivation factors. Therefore, a total of $3^{3}=27$ experiments with different combinations of each factor were conducted (Table 1). All experiments were carried out in biological triplicate $(n=3)$. Cells $(10 \mathrm{~mL})$ for each flask were harvested on the 10th day after initiating the stress, and cell pellets were stored in labelled tubes at $-20^{\circ} \mathrm{C}$ until further analysis. Initially, D. tertiolecta $\left(1 \times 10^{5}\right.$ cells $\left.\mathrm{mL}^{-1}\right)$ were inoculated into modified Johnson medium (J/I) (pH 7.5) containing $\mathrm{NaCl}\left(87.66 \mathrm{~g} \mathrm{~L}^{-1}\right.$ ) (Xu et al. (2016), and grown in glass flasks placed inside a static incubator at $20^{\circ} \mathrm{C} \pm 1$ under

Table 1 Factorial design of light, temperature, and nitrogen levels

\begin{tabular}{|c|c|c|c|}
\hline Experiment & $\begin{array}{l}\text { Light ( } \mu \text { mol photons } \\
\left.\mathrm{m}^{-2} \mathrm{~s}^{-1}\right)\end{array}$ & $\begin{array}{l}\text { Temperature } \\
\left({ }^{\circ} \mathrm{C}\right)\end{array}$ & $\begin{array}{l}\text { Nitrogen concentration } \\
\left(\mathrm{mM} \mathrm{KNO}_{3}\right)\end{array}$ \\
\hline 1 & 15 & 10 & 0.05 \\
\hline 2 & 15 & 10 & 0.5 \\
\hline 3 & 15 & 10 & 5 \\
\hline 4 & 15 & 20 & 0.05 \\
\hline 5 & 15 & 20 & 0.5 \\
\hline 6 & 15 & 20 & 5 \\
\hline 7 & 15 & 30 & 0.05 \\
\hline 8 & 15 & 30 & 0.5 \\
\hline 9 & 15 & 30 & 5 \\
\hline 10 & 145 & 10 & 0.05 \\
\hline 11 & 145 & 10 & 0.5 \\
\hline 12 & 145 & 10 & 5 \\
\hline 13 & 145 & 20 & 0.05 \\
\hline 14 & 145 & 20 & 0.5 \\
\hline 15 & 145 & 20 & 5 \\
\hline 16 & 145 & 30 & 0.05 \\
\hline 17 & 145 & 30 & 0.5 \\
\hline 18 & 145 & 30 & 5 \\
\hline 19 & 550 & 10 & 0.05 \\
\hline 20 & 550 & 10 & 0.5 \\
\hline 21 & 550 & 10 & 5 \\
\hline 22 & 550 & 20 & 0.05 \\
\hline 23 & 550 & 20 & 0.5 \\
\hline 24 & 550 & 20 & 5 \\
\hline 25 & 550 & 30 & 0.05 \\
\hline 26 & 550 & 30 & 0.5 \\
\hline 27 & 550 & 30 & 5 \\
\hline
\end{tabular}


LED (light-emitting diode) light (mixture of cool and warm white) irradiation $\left(145 \mu \mathrm{mol}\right.$ photons $\mathrm{m}^{-2} \mathrm{~s}^{-1}$ ) with a light/ dark cycle (12:12 h). Culturing flasks were shaken manually once a day during cell growth. Cells $\left(1 \times 10^{6}\right.$ cells $\left.\mathrm{mL}^{-1}\right)$ at exponential growth phase were harvested by centrifugation $\left(2000 \times g, 10 \mathrm{~min}, 4{ }^{\circ} \mathrm{C}\right)$. Pellets were reconstituted into conical flasks $\left(200 \mathrm{~mL}, 1 \times 10^{6}\right.$ cells $\left.\mathrm{mL}^{-1}\right)$ and were placed in a static incubator and exposed to the desired levels of continuous LED light irradiation, temperatures, and nitrogen levels as described in Table 1.

\section{Cell Density}

The cell number in cultures was counted using the Neubauer haemocytometer (Weber, UK). A cell suspension $(0.015 \mathrm{~mL})$ was mixed with a formalin solution $(2 \%)$, and the total number of cells was determined.

\section{Pigment Content}

Fresh cells ( $1 \mathrm{~mL}$ culture) were harvested by centrifugation $\left(4000 \times g, 4{ }^{\circ} \mathrm{C}, 10 \mathrm{~min}\right)$. The pellet was homogenised in extracting solution $(80 \% \mathrm{v} / \mathrm{v}$ acetone) using a vortex mixer. The coloured supernatant was separated by centrifugation $\left(14,000 \times g, 4{ }^{\circ} \mathrm{C}, 10 \mathrm{~min}\right)$ and used for pigment analysis. The absorbance was measured against a blank of $80 \%$ acetone solution at 480, 647, and $663 \mathrm{~nm}$ using a spectrophotometer (Jenway 6305, UK). Chlorophyll a (Chl a), chlo-

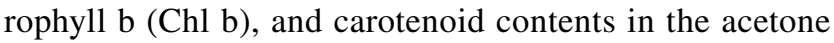
extract $\left(\mu \mathrm{g} \mathrm{mL}^{-1}\right)$ were calculated using the following relationship (Eqs. 1-4) (Takache et al. 2015; Xu et al. 2016).

Total carotenoid $(\mu \mathrm{g} \mathrm{mL}-1)=4.0\left(\mathrm{Abs}_{480}\right)$

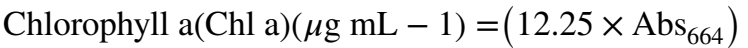

$$
-\left(2.55 \times \mathrm{Abs}_{647}\right)
$$

Chlorophyll $\mathrm{b}(\mathrm{Chl} \mathrm{b})(\mu \mathrm{g} \mathrm{mL}-1)=\left(20.31 \times \mathrm{Abs}_{647}\right)$

$$
-\left(4.91 \times \mathrm{Abs}_{664}\right)
$$

Total chlorophyll $\left(\mu \mathrm{g} \mathrm{mL}^{-1}\right)=(\mathrm{ChL} \mathrm{a})\left(\mu \mathrm{g} \mathrm{mL}^{-1}\right)$

$$
+(\mathrm{ChL} \mathrm{b})\left(\mu \mathrm{g} \mathrm{mL}^{-1}\right)
$$

where $\mathrm{Abs}_{480} \mathrm{~nm}, \mathrm{Abs}_{647} \mathrm{~nm}$, and $\mathrm{Abs}_{664} \mathrm{~nm}$ are the absorbance of the acetone extract measured at 480, 647, and $664 \mathrm{~nm}$, respectively.

\section{Phenolic Content}

Fresh cells (10 mL culture) were harvested by centrifugation $\left(1400 \times g, 4^{\circ} \mathrm{C}, 15 \mathrm{~min}\right)$, and the pellet was homogenised in deionised water $\left(\mathrm{dH}_{2} \mathrm{O}\right)(1 \mathrm{~mL})$. After mixing ( $1 \mathrm{~min}$, vortexed), the suspension was transferred to a sterile Eppendorf $(1.5 \mathrm{~mL})$ tube and incubated $(30 \mathrm{~min}$, sonication) following the protocol described by Falleh et al. (2012) and Machu et al. (2015) with some modifications. After centrifugation $\left(14,000 \times g, 4{ }^{\circ} \mathrm{C}, 15 \mathrm{~min}\right)$, the supernatant was kept on ice $(10 \mathrm{~min})$ and used for determination of total (water-soluble) phenolic content. Total phenolic content in the extract was determined as described by Kuda et al. (2005) using a standard calibration curve of gallic acid $\left(0.1-8 \mu \mathrm{g} \mathrm{mL}^{-1}\right)$. A cell extract $(0.2 \mathrm{~mL})$ was transferred to a clean plastic cuvette $(l=0.1 \mathrm{~cm})$ containing Folin-Ciocalteu (FC) reagent $(0.4 \mathrm{~mL}, 10 \% \mathrm{v} / \mathrm{v})$ and incubated (3 min, room temperature). After adding $\mathrm{Na}_{2} \mathrm{CO}_{3}$ $(10 \% \mathrm{w} / \mathrm{v}, 0.8 \mathrm{~mL})$, the reaction mixture was incubated ( $1 \mathrm{~h}$, room temperature) and the absorbance was taken at $750 \mathrm{~nm}$ (Jenway 6305, UK) against a blank sample containing $\mathrm{dH}_{2} \mathrm{O}(0.2 \mathrm{~mL})$ instead of cells extract in the reaction mixture. The total phenolic compound in the crude extract was expressed as gallic acid equivalent (GAE).

\section{Protein Content}

Fresh cells ( $10 \mathrm{~mL}$ culture) were harvested by centrifugation $\left(1400 \times \mathrm{g}, 4^{\circ} \mathrm{C}, 15 \mathrm{~min}\right)$, and the pellet was homogenised in $\mathrm{NaOH}(5 \mathrm{~mL}, 0.1 \mathrm{mM})$. After incubation (continuous agitation, $250 \mathrm{rpm}, 45 \mathrm{~min}, 40^{\circ} \mathrm{C}$ ), the supernatant was separated by centrifugation $\left(21,000 \times g, 4{ }^{\circ} \mathrm{C}, 30 \mathrm{~min}\right)$ and collected as the first extract. A second extraction was carried out for the residue, and the second supernatant was mixed with the first extract and used for protein assay. Total protein content in the crude extract was determined by the method of Lowry assay (Martina and Vojtech 2015) using ovalbumin as the protein standard.

\section{$\mathrm{H}_{2} \mathrm{O}_{2}$ Content}

Fresh cells (10 mL culture) were harvested by centrifugation $\left(1400 \times g, 4{ }^{\circ} \mathrm{C}, 15 \mathrm{~min}\right)$, and the pellet was homogenised in a $1.0 \mathrm{~mL}$ reaction mixture (trichloroacetic acid (TCA), $0.25 \% \mathrm{w} / \mathrm{v}$; potassium iodide (KI), $25 \mathrm{mM}$; phosphate buffer, $2.5 \mathrm{mM}$, pH 7.0). After mixing (3 min, vortex), the homogenate was transferred to a sterile Eppendorf tube $(1.5 \mathrm{~mL})$ and incubated $(20 \mathrm{~min})$ on an ice bath in the dark. After centrifugation $\left(12,000 \times g, 4{ }^{\circ} \mathrm{C}, 15 \mathrm{~min}\right)$, the supernatant was incubated (20 min, room temperature) and the absorbance was recorded at $350 \mathrm{~nm}$ against blank prepared by adding $\mathrm{dH}_{2} \mathrm{O}(0.5 \mathrm{~mL})$ instead of $\mathrm{KI}$ into the reaction mixture (Junglee et al. 2014). A calibration curve for quantifying hydrogen peroxide $\left(\mathrm{H}_{2} \mathrm{O}_{2}\right)$ content was prepared using standard solutions of $\mathrm{H}_{2} \mathrm{O}_{2}(0.06-0.310 \mathrm{nM})$ and estimated as above. 


\section{Lipid Peroxide (MDA) Content}

Fresh cells ( $10 \mathrm{~mL}$ culture) were harvested by centrifugation $\left(1400 \mathrm{xg}, 4{ }^{\circ} \mathrm{C}, 15 \mathrm{~min}\right)$ and the pellet was homogenised in $1.4 \mathrm{~mL}$ reaction mixture (Thiobarbituric acid (TBA), $0.3 \% \mathrm{w} / \mathrm{v}$; TCA, $3.9 \% \mathrm{w} / \mathrm{v}$ ). After mixing ( $3 \mathrm{~min}$, vortex), the homogenate was transferred to a sterile Eppendorf $(1.5 \mathrm{~mL})$ tube and heated $\left(30 \mathrm{~min}, 95^{\circ} \mathrm{C}\right)$. The mixture was incubated $(10 \mathrm{~min})$ on ice. After centrifugation $\left(12,000 \times g, 4{ }^{\circ} \mathrm{C}, 10 \mathrm{~min}\right)$, the absorbance of the supernatant was recorded (532 and $600 \mathrm{~nm}$ ) using a spectrophotometer (Jenway 6305, UK). A blank sample containing $1.4 \mathrm{~mL}$ reaction mixture (TBA, $0.3 \% \mathrm{w} / \mathrm{v}$; TCA, 3.9\% w/v) was also prepared. In this assay, total lipid peroxide content was quantified as malondialdehyde (MDA) levels (nmoL $10^{-6}$ cells) and calculated using the following formula (Eq. 5) (Hodges et al. 1999; Shah et al. 2001).

MDA equivalents $(\mathrm{nmoL} \mathrm{mL}-1)=\frac{(\mathrm{A} 532-\mathrm{A} 600) \times 10-6}{(155,000)}$

where $532 \mathrm{~nm}$ represented the maximum absorbance of the TBA-MDA complex; $600 \mathrm{~nm}$ represented the correction for non-specific turbidity; $155,000\left(\mathrm{M}^{-1} \mathrm{~cm}^{-1}\right)=$ the molar extinction coefficient of MDA.

\section{Ascorbate and Dehydroascorbate Content}

Fresh cells ( $10 \mathrm{~mL}$ culture) were harvested by centrifugation $\left(1400 \times g, 4{ }^{\circ} \mathrm{C}, 15 \mathrm{~min}\right)$, and the pellet was homogenised in TCA $(0.5 \mathrm{~mL}, 10 \% \mathrm{w} / \mathrm{v})$ and transferred into a sterile and clean Eppendorf tube $(1.5 \mathrm{~mL})$. The tube was shaken $(5 \mathrm{~min})$ vigorously using a vortex mixer and incubated (10 min) on ice. After centrifugation $\left(4000 \times g, 4{ }^{\circ} \mathrm{C}\right.$, $10 \mathrm{~min}$ ), the supernatant was collected as crude extract and kept on ice for spectrophotometric determination ascorbate (ASc) and dehydroascorbate (DASc) content. An aliquot of the cell extract $(0.1 \mathrm{~mL})$ was transferred to a clean plastic cuvette $(l=1 \mathrm{~cm})$ containing $0.9 \mathrm{~mL}$ assay mixture (phosphate buffer $(0.25 \mathrm{~mL}, 100 \mathrm{mM}, \mathrm{pH} 7.00)$, ethylenediaminetetraacetic acid (EDTA) $(100 \mathrm{~mL}, 10 \mathrm{mM})$, and $\mathrm{dH}_{2} \mathrm{O}$ $(0.5 \mathrm{~mL}))$. After adding $\mathrm{FC}$ reagent $(0.2 \mathrm{~mL}, 10 \% \mathrm{v} / \mathrm{v})$, the reaction mixture was shaken vigorously ( $5 \mathrm{~min}$, vortexing, room temperature) and the absorbance was measured $(760 \mathrm{~nm})$ against a blank sample containing TCA $(0.1 \mathrm{~mL}$, $10 \%$ ) instead of cells extract (Jagota and Dani 1982). A calibration curve of a standard solution of ascorbic acid (in $\left.\mathrm{dH}_{2} \mathrm{O}\right)(0.5-5 \mu \mathrm{g})$ was used for quantifying ascorbate content.

An aliquot of cell extract $(0.1 \mathrm{~mL})$ was transferred to a clean plastic cuvette $(l=1 \mathrm{~cm})$ containing $0.85 \mathrm{~mL}$ assay mixture (phosphate buffer $(0.25 \mathrm{~mL}, 100 \mathrm{mM}, \mathrm{pH} 7.00)$,
EDTA $(100 \mathrm{~mL}, 10 \mathrm{mM}), \mathrm{dH}_{2} \mathrm{O}(0.400 \mathrm{~mL})$, and DTT $(30 \mathrm{mM}, 0.05 \mathrm{~mL}))$ and incubated $(10 \mathrm{~min}$, room temperature) to facilitate the reduction of DASc to ASc. After adding N-ethylmaleimide (NEM) $(0.5 \% \mathrm{w} / \mathrm{v}, 0.05 \mathrm{~mL})$, the reaction mixture was incubated (5 min, room temperature) and FC reagent $(0.2 \mathrm{~mL}, 10 \% \mathrm{v} / \mathrm{v})$ was added. The reaction mixture was shaken vigorously ( $5 \mathrm{~min}$, vortexing, room temperature), and the absorbance was measured $(760 \mathrm{~nm})$ against a blank sample containing TCA $(0.1 \mathrm{~mL}$, $10 \%$ ) instead of cells extract (Jagota and Dani 1982). Total reduced ascorbate (TASc) was calculated from the calibration curve. The DASc content was estimated by subtraction of the amount of reduced ascorbate (ASc) from the TASc content.

\section{Total Glutathione Content and Reduced Flutathione Content}

Fresh cells $(10 \mathrm{~mL})$ were harvested by centrifugation $\left(1400 \times \mathrm{g}, 4^{\circ} \mathrm{C}, 15 \mathrm{~min}\right)$, and the pellet homogenised in $0.5 \mathrm{~mL}$ extraction buffer $(50 \mathrm{mM}$ sulfosalicylic acid, $1 \mathrm{mM}$ EDTA, and $8.5 \mathrm{mM}$ ascorbic acid) followed by cell disruption by vortexing in the presence of silica beads and sonication ( $2 \mathrm{~min})$. After centrifugation $\left(14,000 \times g, 4^{\circ} \mathrm{C}, 15 \mathrm{~min}\right)$, the supernatant was collected in a sterile Eppendorf tube $(1.5 \mathrm{~mL})$ and kept on ice for determination of glutathione content.

An aliquot of cell extract $(0.2 \mathrm{~mL})$ was transferred to a clean plastic cuvette $(l=1 \mathrm{~cm})$ containing $0.9 \mathrm{~mL}$ assay mixture (5,5-dithiobis-2-nitrobenzoic acid (DTNB), $8.6 \mathrm{mM}$, glutathione reductase (GR) $2.73 \mathrm{U}$ in phosphate buffer (100 mM, pH 7.00)). Phosphate buffer $(0.1 \mathrm{~mL}, 100 \mathrm{mM}$, $\mathrm{pH}$ 7.00) was added to the reaction mixture and incubated (30 min, room temperature). After adding NADPH solution $(0.75 \mathrm{~mL}, 0.827 \mathrm{mM})$ and mixing (gentle inversion), the cuvette was placed inside the spectrophotometer (Jenway $6305, \mathrm{UK})$. The change in optical density $(\Delta \mathrm{OD})$ due to the production of 5-thio-2-nitrobenzoic acid (TNB) was recorded (0 min, $5 \mathrm{~min}$ ) at $412 \mathrm{~nm}$ against a blank sample containing extraction buffer instead of cell extract. A calibration curve for quantifying total glutathione (TGSH) was prepared using standard reduced glutathione $(0.312-25 \mathrm{nmol})$. The TGSH content in cell extract was calculated using Eq. 6 (Salbitani et al. 2017).

Reduced glutathione (GSH) level was estimated using the same procedure as TGSH but excluding the GR and NADPH in the reaction mixture. The reaction mixture $(1.275 \mathrm{~mL})$ contained DTNB $(0.9 \mathrm{~mL}, 8.6 \mathrm{mM})$ in phosphate buffer (100 mM, pH 7.00), phosphate buffer (0.175 mL, $100 \mathrm{mM}, \mathrm{pH} 7.00)$, and cell extract $(0.2 \mathrm{~mL})$. DTNB is converted into TNB in this assay due to the only participation of GSH. After incubation ( $5 \mathrm{~min}$, room temperature) and mixing gently (by inversion), the absorbance 
of the reaction mixture recorded spectrophotometrically (412 $\mathrm{nm})$ against a blank sample containing extraction buffer instead of cells extract. GSH content was estimated using Eq. 6.

Total glutathione content $\left[\mathrm{nmol}\left(10^{-6}\right.\right.$ cells $\left.)\right]$

$$
=\frac{\left(\Delta \mathrm{OD}_{\mathrm{s}}\right) \times \text { total volume }(\mathrm{mL})}{\left(\Delta \mathrm{OD}_{\text {std }}\right) \times \text { Sample volume }(\mathrm{mL}) \times \text { length }(\mathrm{cm})}
$$

where $\Delta \mathrm{OD}_{\mathrm{S}}=$ optical density changes due to GSH in sample; $\Delta \mathrm{OD}_{\mathrm{Std}}=$ optical density changes due to standard GSH solution.

\section{Determination of Antioxidant Enzyme Activity}

\section{Preparation of Crude Extract}

Crude extract for enzymes assay (CAT, POD, and SOD) were prepared from $D$. tertiolecta fresh cell pellet (culture $(10 \mathrm{~mL})$ harvested by centrifugation $\left(3000 \times g, 15 \mathrm{~min}, 4^{\circ} \mathrm{C}\right)$ using a modified method described by Tian and Yu (2009). A cell pellet was dissolved in an extraction buffer $(1 \mathrm{~mL}$, $50 \mathrm{mM}$ potassium phosphate buffer (0.1 mM EDTA, $0.1 \%$ Triton $\mathrm{X}-100,1 \%$ polyvinylpyrrolidone (PVP), and $\mathrm{pH} 7.5$ ) and transferred into a sterilized Eppendorf tube $(1.5 \mathrm{~mL})$. The homogenate was vortexed $(5 \mathrm{~min})$ in the presence of silica beads $(0.2 \mathrm{~g})$, and the supernatant was separated after centrifugation $\left(13,000 \times g, 30 \mathrm{~min}, 4{ }^{\circ} \mathrm{C}\right)$. The supernatant was used in the subsequent analysis for the antioxidant enzyme activity. Total protein content in crude extract was measured using Lowry assay with ovalbumin as protein standard.

\section{CAT Activity}

Extract $(0.05 \mathrm{~mL})$ were transferred to a quartz cuvette $(l=0.1 \mathrm{~cm})$ containing ice-cold phosphate buffer $(1 \mathrm{~mL}$, $50 \mathrm{mM}, \mathrm{pH}$ 7.00) (Zhang et al. 2015). The reaction mixture was equilibrated $\left(25^{\circ} \mathrm{C}, 5 \mathrm{~min}\right)$ and $\mathrm{H}_{2} \mathrm{O}_{2}(0.05 \mathrm{~mL}$, $858 \mathrm{mM}$ ) was added (final concentrations $\mathrm{H}_{2} \mathrm{O}_{2} 0.045 \mathrm{mM}$ and phosphate buffer $39 \mathrm{mM}$ ). After mixing (gentle inversion), decrease in optical density $(\Delta \mathrm{OD})$ was recorded (every $10 \mathrm{~s}, 5 \mathrm{~min}, 240 \mathrm{~nm}$ ) against a blank sample containing $\mathrm{dH}_{2} \mathrm{O}$ in the reaction mixture instead of extract. The specific CAT activity was calculated as units per milligram of protein (Tian and Yu 2009), Eq. 7.

CAT activity( $\mathrm{U} \mathrm{mg}-1$ protein)

$=\frac{(\mathrm{OD} \mathrm{min}-1) \times \text { total volume }(\mathrm{mL}) \times \mathrm{df}}{0.0436 \times \text { sample volume }(\mathrm{mL}) \times \text { protein content }(\mathrm{mg} \mathrm{mL}-1) \times \text { length }(\mathrm{cm})}$

where $0.0436=$ millimolar extinction coefficient of $\mathrm{H}_{2} \mathrm{O}_{2}$ at $240 \mathrm{~nm}, \mathrm{df}=$ dilution factor.

\section{POD Activity Assay}

ABTS (2,2'-azino bis ( 3 ethylbenzthiazoline-6-sulfonic acid) solution $(0.964 \mathrm{~mL}, 9.1 \mathrm{mM})$ in phosphate buffer $(100 \mathrm{mM}$, $\mathrm{pH} 5.00)$ and extract $(0.01 \mathrm{~mL})$ was transferred to a quartz cuvette $(l=0.1 \mathrm{~cm})$ and placed inside the spectrophotometer. After equilibration $\left(25^{\circ} \mathrm{C}, 5 \mathrm{~min}\right)$ of the reaction mixture, $\mathrm{H}_{2} \mathrm{O}_{2}(0.036 \mathrm{~mL}, 88.5 \mathrm{mM})$ was added, and the change in optical density $(\triangle \mathrm{OD})$ was recorded (every $10 \mathrm{~s}, 3 \mathrm{~min}$, $420 \mathrm{~nm}$ ) against a blank sample containing $\mathrm{dH}_{2} \mathrm{O}$ in the reaction mixture instead of extract. The specific POD activity was calculated as units per mg of protein, Eq. 8 .

$$
\begin{aligned}
& \text { POD activity }(\mathrm{U} \mathrm{mg}-1 \text { protein }) \\
& =\frac{(\mathrm{OD} \mathrm{min}-1) \times \text { total volume }(\mathrm{mL}) \times \mathrm{df}}{36.8 \times \text { sample volume }(\mathrm{mL}) \times \text { protein content }(\mathrm{mg} \mathrm{mL}-1) \times \text { length }(\mathrm{cm})}
\end{aligned}
$$

where $36.8=$ millimolar extinction coefficient of ABTS, $\mathrm{df}=$ dilution factor.

\section{SOD Activity Assay}

Phosphate buffer $(0.667 \mathrm{~mL}, 75 \mathrm{mM}, \mathrm{pH} 7.00), \mathrm{dH}_{2} \mathrm{O}$ $(0.06 \mathrm{~mL})$, xanthine $(0.1 \mathrm{~mL}, 150 \mathrm{mM})$, and NBT $(0.1 \mathrm{~mL}$, $1.5 \mathrm{mM})$ was transferred into a quartz cuvette $(\mathrm{d}=0.1 \mathrm{~cm})$. After equilibration $\left(25^{\circ} \mathrm{C}, 5 \mathrm{~min}\right)$ of the reaction mixture, xanthine $\left(0.023 \mathrm{~mL}, 0.4 \mathrm{U} \mathrm{mL}^{-1}\right)$ oxidase was added to it, and the optical density $(\Delta \mathrm{OD})$ was recorded (per second, $3 \mathrm{~min}, 560 \mathrm{~nm}$ ) against a blank sample containing $\mathrm{dH}_{2} \mathrm{O}$ in reaction mixture instead of xanthine oxidase. After $3 \mathrm{~min}$, the extract $(0.05 \mathrm{~mL})$ was added into the reaction mixture, and the decrease in optical density $(\Delta \mathrm{OD})$ was recorded up to $7 \mathrm{~min}$. The specific SOD activity was calculated as units per $\mathrm{mg}$ of protein using the following formula, Eqs. 9-10.

Percent inhibition $(\%)$

$=\frac{(\Delta \text { ODs } \min -1-\Delta \text { ODO } \min -1) \times 100}{(\Delta \text { ODs min }-1)}$

Increase in absorbance (uninhibited) per $\min \left(\Delta \mathrm{OD}_{\mathrm{s}}\right.$ $\mathrm{min}^{-1}$ ) at $560 \mathrm{~nm}$.

Inhibition of absorbance per min $\left(\Delta \mathrm{OD}_{\mathrm{o}} \mathrm{min}^{-1}\right)$ by the sample at $560 \mathrm{~nm}$.

$$
\begin{aligned}
& \text { SOD activity }(\mathrm{U} \mathrm{mg}-1 \text { protein }) \text { in extract } \\
& =\frac{\text { Percent inhibition } \times \mathrm{df}}{50 \% \times \text { sample volume }(\mathrm{mL}) \times \mathrm{U} \mathrm{mg}-1 \text { protein }}
\end{aligned}
$$

\section{Statistical Analysis}

The individual and the interactive effect of light, temperature, and nitrogen concentration on all accumulated biomolecules including antioxidant enzyme activity were evaluated 

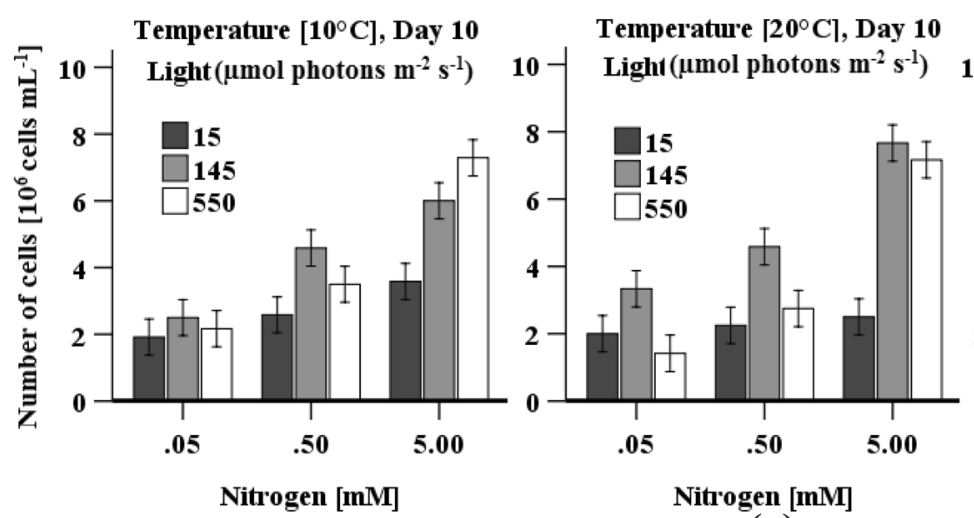

(a)

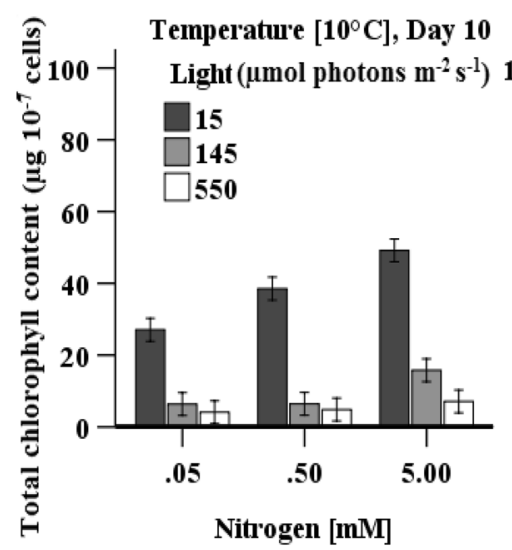

Temperature $\left[10^{\circ} \mathrm{C}\right]$, Day 10

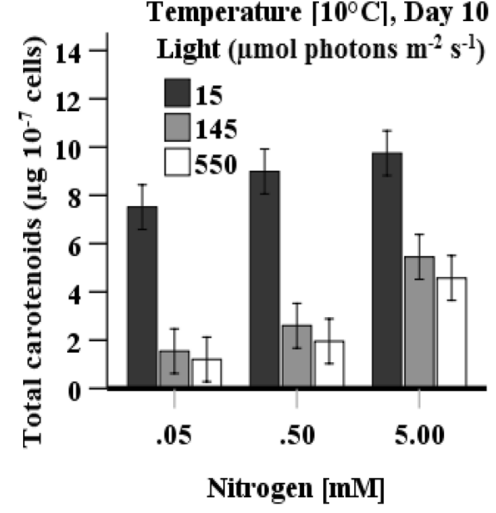

Nitrogen [mM]

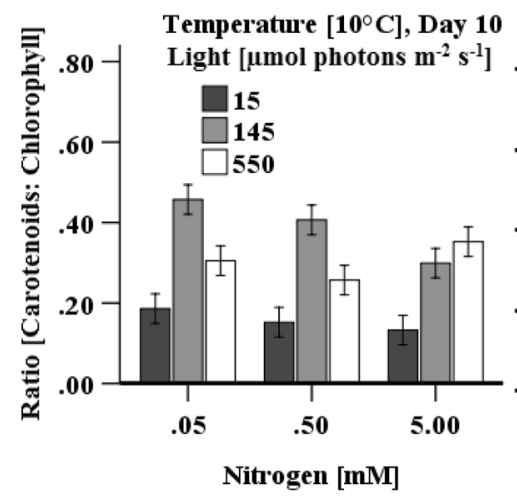

Nitrogen [mM]

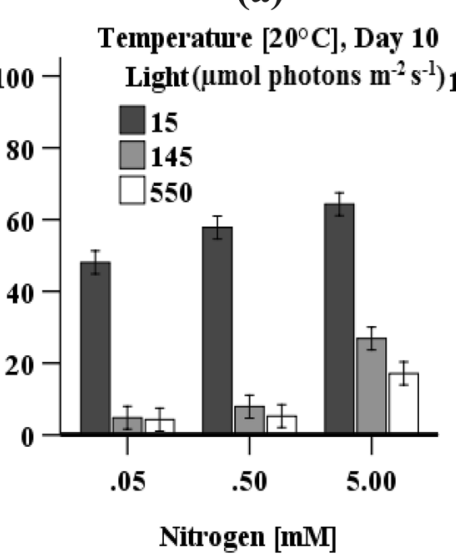

(b)

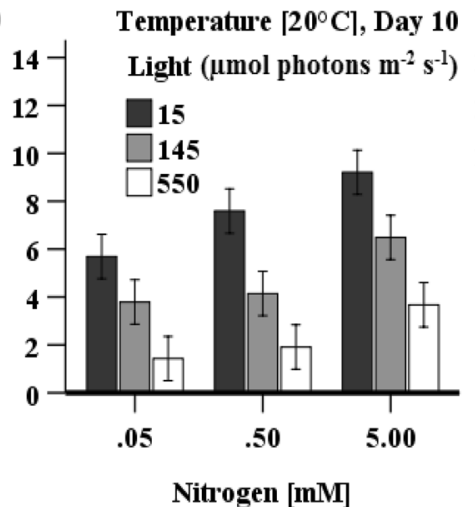

(c)

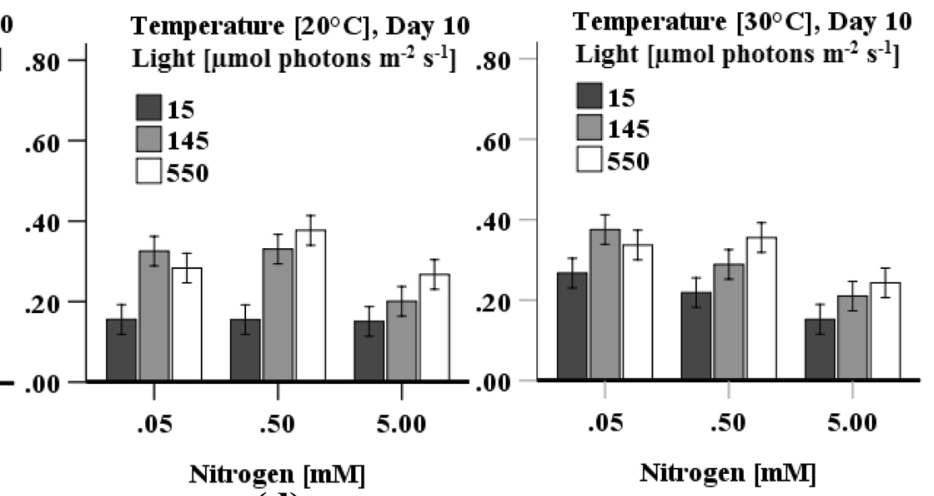

Temperature $\left[3^{\circ} \mathrm{C}\right]$, Day 10

Light ( $\mu \mathrm{mol}$ photons $\mathrm{m}^{-2} \mathrm{~s}^{-1}$ )

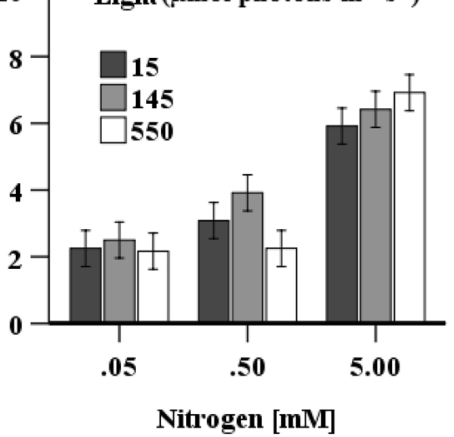

Temperature $\left[30^{\circ} \mathrm{C}\right]$, Day 10

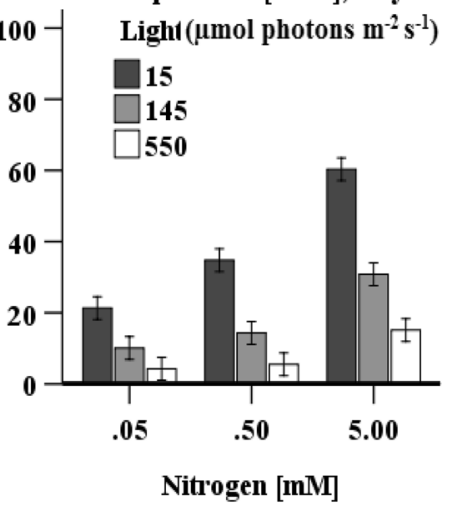

Temperature $\left[30^{\circ} \mathrm{C}\right]$, Day 10

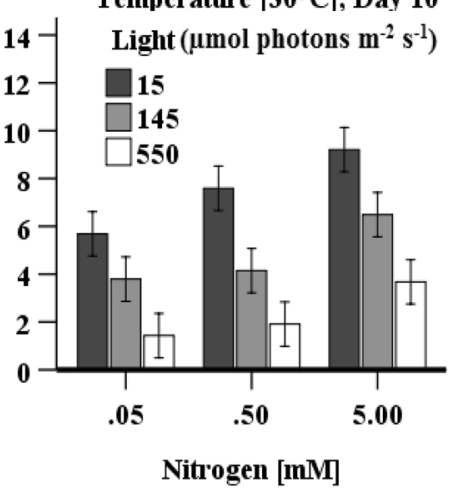

(d) 
4Fig. 1 Effect of light, temperature, and nitrogen concentration on a cell density, b chlorophyll, $\mathbf{c}$ carotenoid content, and $\mathbf{d}$ ratio of chlorophyll to carotenoids (Car:Chl) in D. tertiolecta cultures. Data is presented as mean $\pm \mathrm{SE}(n=3)$

using $3^{3}$ factorial ANOVAs with light levels $(15,145$, $550 \mu \mathrm{mol}$ photons $\left.\mathrm{m}^{-2} \mathrm{~s}^{-1}\right)$, temperature $\left(10,20,30^{\circ} \mathrm{C}\right)$, and nitrogen level $\left(0.05,0.5,5 \mathrm{mM} \mathrm{KNO}_{3}\right)$ as experimental factors (SPSS software (IBM, USA). A $t$-test (non-equal variance) was performed when comparing two means. $R$ software (The comprehensive $\mathrm{R}$ archive network) was used to confirm normality. Tukey's HSD was carried out for pairwise comparison of factors. Graphical data are represented as means and standard error. To predict the best combination of cultivation factors to obtain maximum individual antioxidant content in D. tertiolecta, Design-Expert experiments (DoE) (full factorial) was conducted using Minitab Statistical Software (Minitab®, Pennsylvania State University).

\section{Results}

The combined effect of light irradiation (chemical energy source), temperature (intracellular enzymatic reactions and biochemical composition), and nitrogen (growth and cellular metabolism) were used to induce oxidative stress to stimulate enzymatic and non-enzymatic antioxidant contents in D. tertiolecta. To assess the overall intracellular antioxidant response, the accumulation of chlorophyll content, cell density, total protein, $\mathrm{H}_{2} \mathrm{O}_{2}$ and MDA content, including enzymatic (CAT, SOD, and POD and non-enzymatic antioxidant (carotenoids, phenolic, ascorbate, and glutathione) levels, were determined.

\section{Cell Density}

Cell density (biomass production) was directly influenced by light irradiation and nitrogen concentration during culturing of D. tertiolecta cells (Fig. 1a). Cell density consistently increased with nitrogen concentration from 0.05 to $5 \mathrm{mM}$ $\mathrm{KNO}_{3}$ under any combination of light and temperature except from cells grown with $0.5 \mathrm{M} \mathrm{KNO}_{3}$ at $30{ }^{\circ} \mathrm{C}$ under $550 \mu \mathrm{mol}$ photons $\mathrm{m}^{-2} \mathrm{~s}^{-1}$. Cells grown with high nitrogen $\left(5 \mathrm{mM} \mathrm{KNO}_{3}\right)$ at light irradiation of 145 or $550 \mu \mathrm{mol}$ photons $\mathrm{m}^{-2} \mathrm{~s}^{-1}$ showed significantly $(p<0.01)$ higher cell density compared to cells exposed to low light irradiation $\left(15 \mu \mathrm{mol}\right.$ photons $\left.\mathrm{m}^{-2} \mathrm{~s}^{-1}\right)$ at all three temperatures (Fig. 1a). The highest cell density $\left(\sim 8 \times 10^{6}\right.$ cells $\left.\mathrm{mL}^{-1}\right)$ was observed in cells grown at $20^{\circ} \mathrm{C}$ under $145 \mu \mathrm{mol}$ photons $\mathrm{m}^{-2} \mathrm{~s}^{-1}$ with high nitrogen content (Fig. 1a); however, no significant $(p>0.05)$ difference in cell densities were observed in cells grown at $10{ }^{\circ} \mathrm{C}$ under $550 \mu \mathrm{mol}$ photons $\mathrm{m}^{-2} \mathrm{~s}^{-1}$ with a high nitrogen content, and in cultures grown at $30^{\circ} \mathrm{C}$ under 145 or $550 \mu \mathrm{mol}$ photons $\mathrm{m}^{-2} \mathrm{~s}^{-1}$ with a high nitrogen content. A three-way ANOVA illustrates that all individual factors except for temperature (ANOVA, $p=0.11, \mathrm{df}=2,54$ ) and all interactive factors had a highly significant influence on cell density $(p<0.0001)$.

\section{Chlorophyll and Total Carotenoid Content}

The accumulation of chlorophyll and total carotenoid content consistently increased with increasing nitrogen concentration and consistently decreased with increasing light irradiation (Fig. 1b, c). Chlorophyll production was also enhanced when cells were grown at $20{ }^{\circ} \mathrm{C}$ under any combination of light and nitrogen compared to cultivation at either $10{ }^{\circ} \mathrm{C}$ or $30^{\circ} \mathrm{C}$, whereas carotenoid production was highest under all condition when cells where cultivated at $10^{\circ} \mathrm{C}$. The highest chlorophyll content $\left(65 \pm 5.14 \mu \mathrm{g} 10^{-7}\right.$ cells) was observed in cells grown at $20^{\circ} \mathrm{C}$ under $15 \mu \mathrm{mol}$ photons $\mathrm{m}^{-2} \mathrm{~s}^{-1}$ with high nitrogen levels (Fig. 1b), whereas the highest carotenoid content $\left(9.75 \pm 1.65 \mu \mathrm{g} 10^{-7}\right.$ cells $)$ was achieved at $10^{\circ} \mathrm{C}$ under the same light and temperature (Fig. 1c). A three-way ANOVA for both chlorophyll and carotenoid content indicates that all individual or combing factors are statistically significant, except for the interaction of light $\times$ temperature $\times$ nitrogen (ANOVA, $p=0.74$, $\mathrm{df}=4,54)$ and light $\times$ nitrogen $($ ANOVA, $p=0.10, \mathrm{df}=2$, 54) which did not have a significant impact on carotenoid content. The Car:Chl ratio increased with a decrease in nitrogen levels and an increase in light irradiation (Fig. 1d). A highest Car:Chl ratio (Fig. 1d) was found in cells grown with low nitrogen $(<0.5 \mathrm{mM})$ under $145 \mu \mathrm{mol}$ photons $\mathrm{m}^{-2} \mathrm{~s}^{-1}$. Conversely, the lowest Car:Chl ratio (0.133) was observed when cells were grown with high nitrogen under low light irradiation, which represents high chlorophyll accumulation.

\section{Protein Content}

Protein content increased as the nitrogen concentration in the medium increased regardless of the changes to other cultivation factors (Fig. 2) except for cultivations with $0.5 \mathrm{mM}$ $\mathrm{KNO}_{3}$ at $10{ }^{\circ} \mathrm{C}$ under $550 \mu \mathrm{mol}$ photons $\mathrm{m}^{-2} \mathrm{~s}^{-1}$, cultivation with $0.05-0.5 \mathrm{mM} \mathrm{KNO}_{3}$ under 15 or $145 \mu \mathrm{mol}$ photons $\mathrm{m}^{-2} \mathrm{~s}^{-1}$ at $30^{\circ} \mathrm{C}$. Protein content was predominantly highest when cells were cultured at either 10 or $20^{\circ} \mathrm{C}$ with a nitrogen concentration of $5 \mathrm{mM} \mathrm{KNO}_{3}$. The highest protein content $\left(1.41 \pm 0.27 \mathrm{mg} 10^{-7}\right.$ cells) was obtained in cells that were grown at $10{ }^{\circ} \mathrm{C}$ under low light irradiation $(15 \mu \mathrm{mol}$ photons $\mathrm{m}^{-2} \mathrm{~s}^{-1}$ ) and with high nitrogen content (5.0 mM) (Fig. 2). A three-way ANOVA indicates that all three factors (individual or interactive) have a statistically significant $(p<0.05)$ impact on protein accumulation, which indicates in the importance in correctly tuning these parameters to enhance protein content. To obtain maximum total protein levels in $D$. tertiolecta, cells 

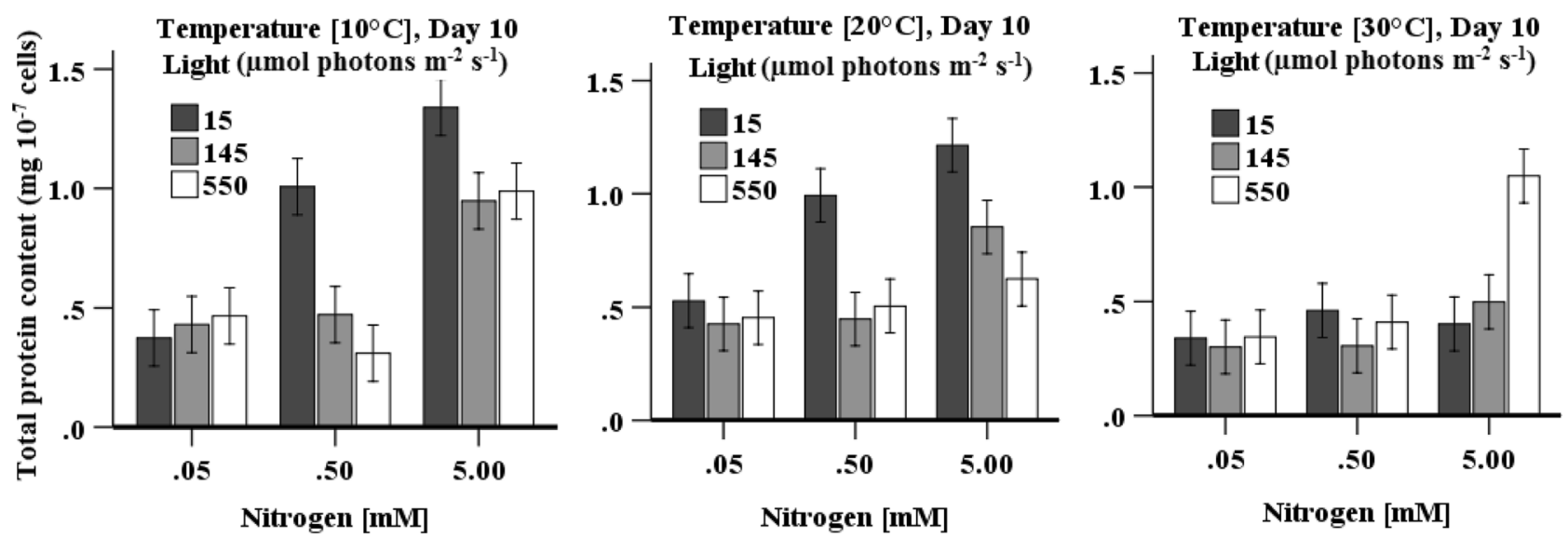

Fig. 2 Effect of light, temperature, and nitrogen concentration on total protein in D. tertiolecta cultures. Data is presented as mean \pm SE $(n=3)$

should be cultured in a high nitrogen-containing medium at low temperature and under low light irradiation.

\section{$\mathrm{H}_{2} \mathrm{O}_{2}$ and MDA Content}

Maximum $\mathrm{H}_{2} \mathrm{O}_{2}$ content ( $19.63 \pm 3.63$ pmol $10^{-7}$ cells) was found when cells were grown with a high nitrogen concentration under medium light irradiation $(145 \mu \mathrm{mol}$ photons $\left.\mathrm{m}^{-2} \mathrm{~s}^{-1}\right)$ and at $20{ }^{\circ} \mathrm{C}$ though not significant different from the $\mathrm{H}_{2} \mathrm{O}_{2}$ content $\left(10.32 \pm 1.12\right.$ pmol $10^{-7}$ cells $)$ accumulated in cells cultivated at high light and low nitrogen concentrations (Fig. 3a). A three-way ANOVA indicates that all individual or interactive factors, except for nitrogen concentration, are statistically significant in accumulating $\mathrm{H}_{2} \mathrm{O}_{2}$ content in cells. The highest MDA content $(1376 \pm 300 \mathrm{pmol}$ $10^{-7}$ cells) was found when cells were grown at $20{ }^{\circ} \mathrm{C}$ with $0.5 \mathrm{mM} \mathrm{KNO}_{3}$ under $550 \mu \mathrm{mol}$ photons $\mathrm{m}^{-2} \mathrm{~s}^{-1}$. Though MDA content $\left(1057 \pm 277\right.$ pmol $10^{-7}$ cells $)$ did not significantly change in cells when grown with $0.05 \mathrm{mM} \mathrm{KNO}_{3}$ under medium light irradiation relative to cells grown with nitrogen concentration $(0.5 \mathrm{mM})$, these contents were significantly $(p<0.05)$ higher relative to cells grown with high nitrogen levels $\left(5 \mathrm{mM} \mathrm{KNO}_{3}\right)$ under similar light irradiation. The data indicate that depletion of nitrogen predominantly induces oxidative stress and subsequently increases the levels of MDA. A three-way ANOVA indicates that all three factors (individual or interactive) have a statistically significant impact on the accumulation of MDA content in D. tertiolecta. $\mathrm{H}_{2} \mathrm{O}_{2}$ content $\left(15.23 \pm 3.61 \mathrm{pmol} 10^{-7}\right.$ cells $)$ was significantly $(p<0.05)$ higher at $10{ }^{\circ} \mathrm{C}$ when cells were cultured with low nitrogen levels under high light irradiation relative to cells grown under low or medium light irradiation with the same temperature and nitrogen levels. Conversely, a significantly $(p<0.05)$ higher MDA content at $10^{\circ} \mathrm{C}$ was obtained in cells when cultured under both low or high light irradiation relative to cells grown under medium light irradiation at the same nitrogen and temperature.

\section{Non-enzymatic Antioxidants}

\section{Phenolic content}

The highest phenolic content $\left(32 \pm 2.6 \mu \mathrm{g}\right.$ GAE $10^{-7}$ cells $)$ was achieved when cells were cultured at $20{ }^{\circ} \mathrm{C}$ under low light irradiation and with a nitrogen concentration of $0.5 \mathrm{mM}$ $\mathrm{KNO}_{3}$ (Fig. 4). Unexpectedly, under $20^{\circ} \mathrm{C}$ cultivation, accumulation of phenolic compounds decreased as light irradiation increased, and the lowest phenolic content was found when cells were grown under high light irradiation $(550 \mu \mathrm{mol}$ photons $\mathrm{m}^{-2} \mathrm{~s}^{-1}$ ) at all three nitrogen levels. This was opposite in cells cultivated at $10{ }^{\circ} \mathrm{C}$ and with $>0.5 \mathrm{mM}$ nitrogen where a significantly $(p<0.05)$ higher phenolic content was observed in cells cultivated under high light irradiation levels relative to cells cultured under low light irradiation (Fig. 4). A three-way ANOVA indicates that all three factors (individuals and interactive) have a statistically significant $(p<0.05)$ impact on phenolic accumulation in cells.

\section{Ascorbate and reduced ascorbate content}

Ascorbate pool (reversible inter-conversion of reduced ascorbate (ASc) to dehydroascorbate (DASc)) is involved in the intracellular physiological process (either as an antioxidant for direct detoxification of ROS or act as an electron donor for ascorbate peroxidase enzyme activity), and levels are influenced by manipulation of factors (light, temperature, and nitrogen concentration) during cultivation. The accumulation of total ascorbate content was significantly higher $(p>0.05)$ in cells when grown at $20{ }^{\circ} \mathrm{C}$ under all light or nitrogen concentrations compared to either 10 or $30{ }^{\circ} \mathrm{C}$ except for the cell growth at $30{ }^{\circ} \mathrm{C}$ with low nitrogen under medium light irradiation (Fig. 5a). In addition, content was significantly higher at $20{ }^{\circ} \mathrm{C}$, under low or high light irradiation relative to medium light irradiation at the same nitrogen concentration, and maximum ascorbate content 


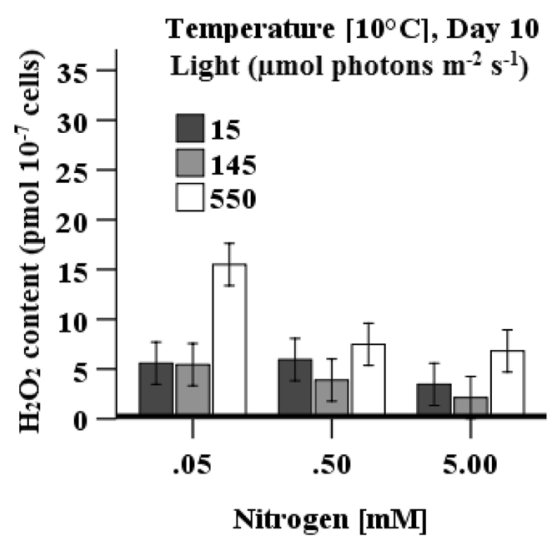

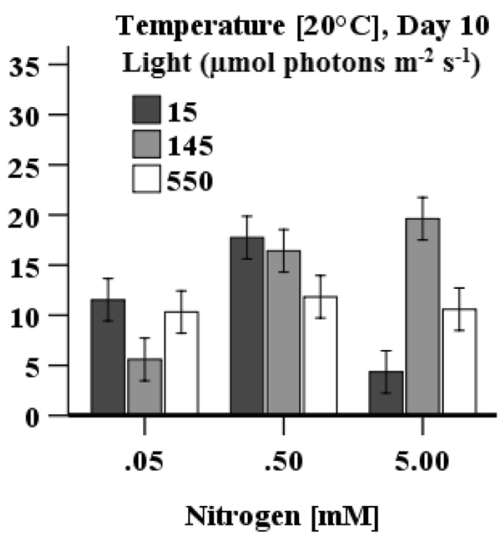

(a)

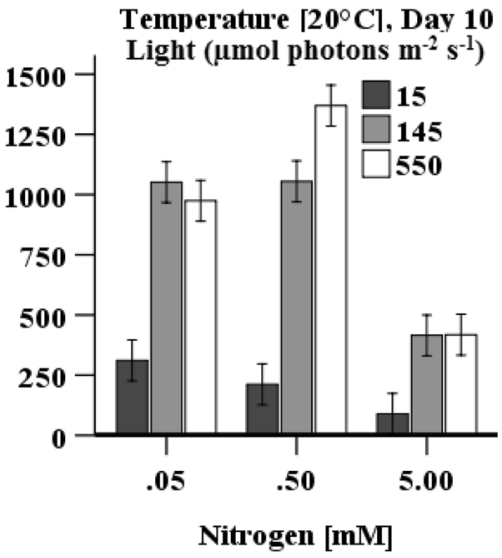

(b)
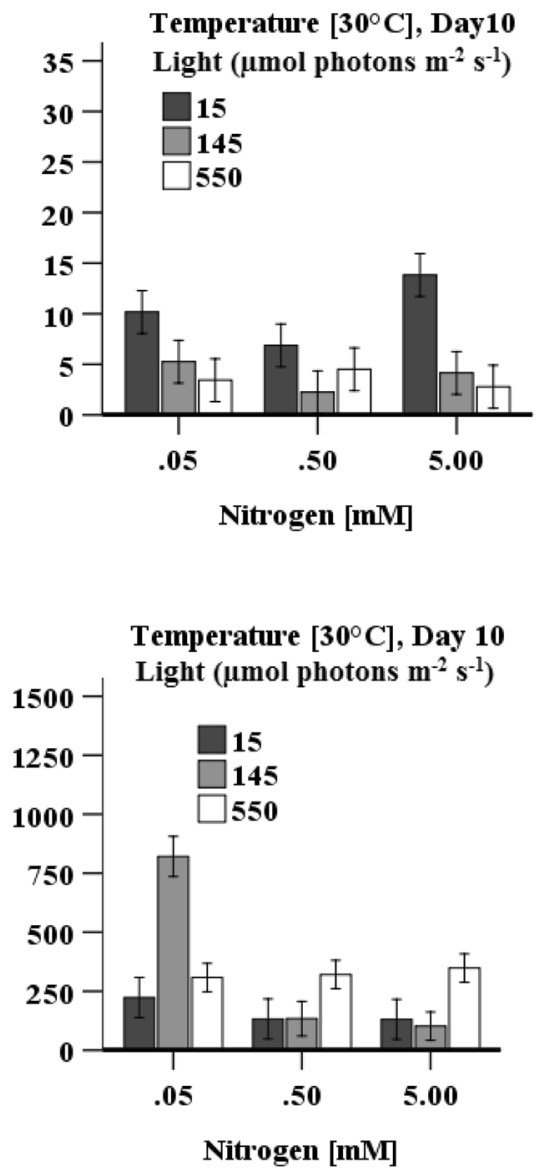

Fig. 3 Effect of light, temperature, and nitrogen concentration on accumulation of $\mathbf{a} \mathrm{H}_{2} \mathrm{O}_{2}$ and $\mathbf{b}$ MDA content in D. tertiolecta cultures. Data is presented as mean $\pm \operatorname{SE}(n=3)$

$\left(200 \pm 17\right.$ nmol $10^{-7}$ cells $)$ was achieved in cells grown with $0.5 \mathrm{mM} \mathrm{KNO}$ under high light irradiation. Though variation in nitrogen concentration $\left(0.5-5 \mathrm{mM} \mathrm{KNO}_{3}\right)$ at $20{ }^{\circ} \mathrm{C}$ did not have a significant impact on total ascorbate content in cells, significantly $(p>0.05)$ lower ascorbate was found when cells were cultured with low nitrogen $(0.05 \mathrm{mM}$ $\mathrm{KNO}_{3}$ ) under low or high light irradiation. A significantly $(p<0.05)$ higher ratio of ASc:DASc was observed in cells grown at $20{ }^{\circ} \mathrm{C}$ under high light irradiation (Fig. 5b) with nitrogen levels of $0.5 \mathrm{mM} \mathrm{KNO}_{3}$ relative to cells cultured with low or high nitrogen under the same light irradiation (Fig. 5b). In contrast, compared to high nitrogen, significantly $(p<0.05)$ lower ratio of ASc:DASc was observed in cells grown with low nitrogen under light irradiation of $145 \mu \mathrm{mol}$ photons $\mathrm{m}^{-2} \mathrm{~s}^{-1}$ at $20^{\circ} \mathrm{C}$, which indicates high DASc content in the cells.
Maximum total ascorbate $\left(170 \pm 32 \mathrm{nmol} 10^{-7}\right.$ cells $)$ content was observed at $30{ }^{\circ} \mathrm{C}$ when cells were grown with low nitrogen under medium light irradiation (Fig. 5a). An increase in ASc:DASc ratio with decreasing nitrogen levels was found when cells were grown at $30{ }^{\circ} \mathrm{C}$ under $>145 \mu \mathrm{mol}$ photons $\mathrm{m}^{-2} \mathrm{~s}^{-1}$, and this ratio was maximum when cells were cultured with medium nitrogen $\left(0.5 \mathrm{mM} \mathrm{KNO}_{3}\right)$ under medium light irradiation.

\section{Total Glutathione and Reduced Glutathione Content}

The accumulation of total glutathione (oxidised + reduced) and GSH content gradually increased with a decrease in nitrogen concentration under all three levels of light irradiation (Fig. 6a, b). A three-way ANOVA indicate that all individual or interactive factors are statistically significant 

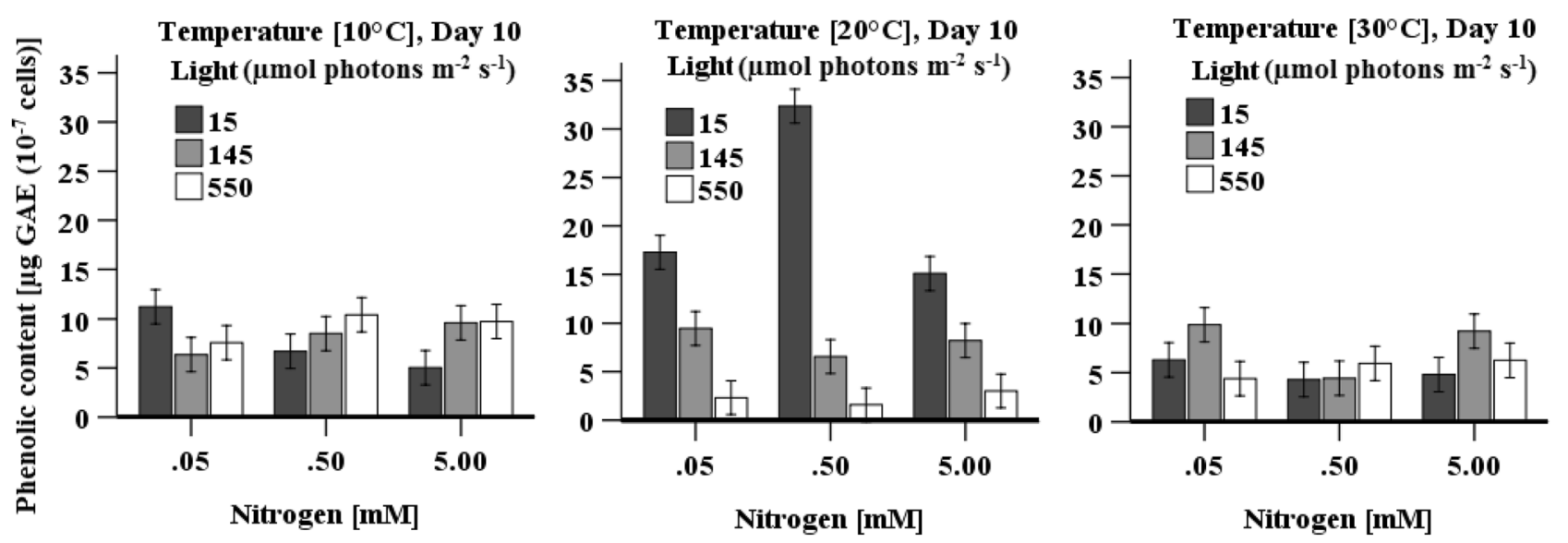

Fig. 4 Effect of light, temperature, and nitrogen concentration on total phenolic contents in D. tertiolecta cultures. Data is presented as mean $\pm \operatorname{SE}(n=3)$
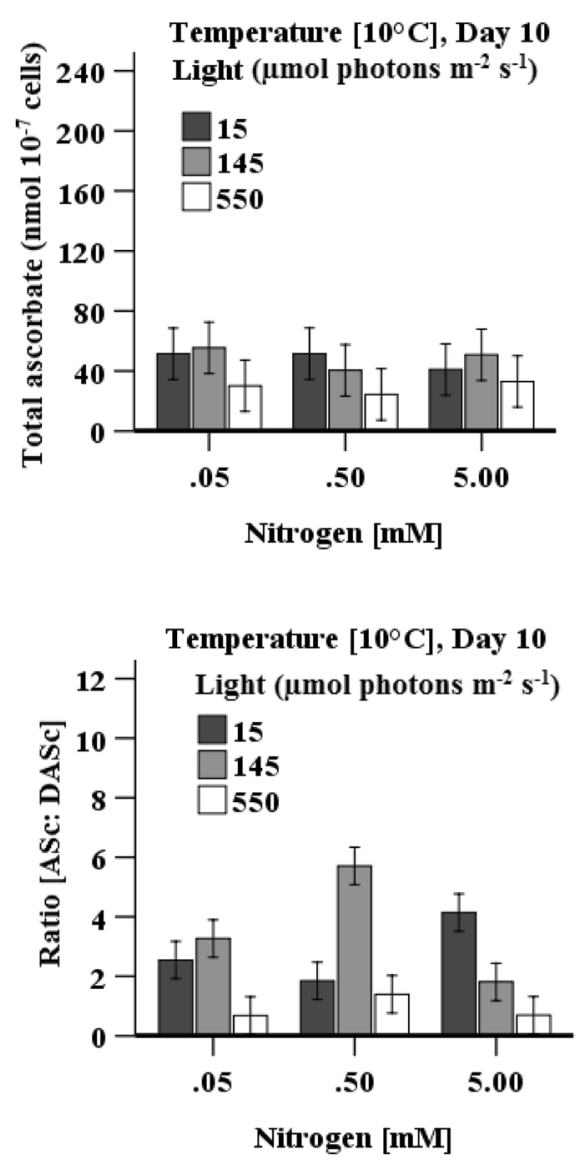

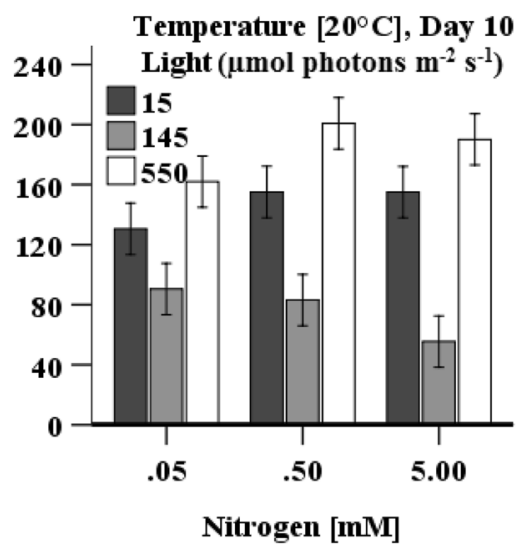

(a)

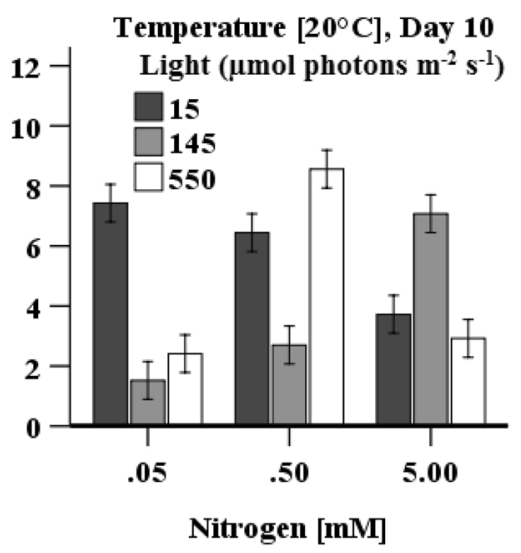

(b)
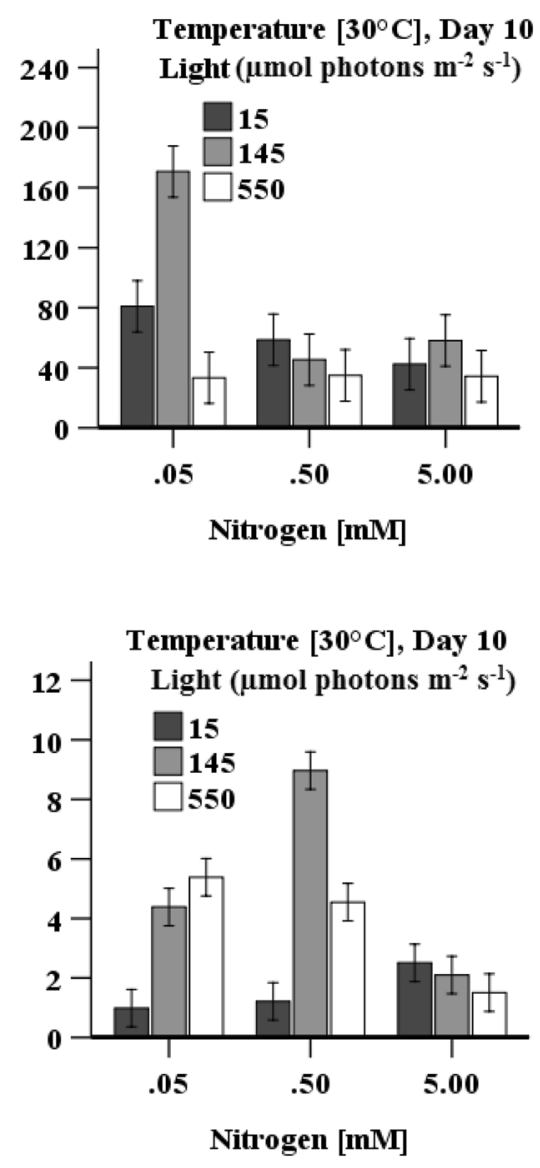

Fig. 5 Effect of light, temperature, and nitrogen concentration on a total ascorbate content and b ratio of ASc:DASc in D. tertiolecta cultures. Data is presented as mean $\pm \operatorname{SE}(n=3)$ 
in accumulating total glutathione content in cells. The concentration of these compounds was significantly $(p<0.05)$ higher in cells when grown with low nitrogen under low but especially high light irradiation relative to cells cultured under medium light $\left(145 \mu \mathrm{mol}\right.$ photons $\left.\mathrm{m}^{-2} \mathrm{~s}^{-1}\right)$ with the same temperature. Maximum total glutathione $(39 \pm 2 \mathrm{nmol}$ $10^{-7}$ cells $)$ and reduced glutathione content $(20 \pm 2 \mathrm{nmol}$ $10^{-7}$ cells) was found in cells grown at $20{ }^{\circ} \mathrm{C}$ with low nitrogen under high light irradiation. Nitrogen concentration did not have significant impact on the accumulation of total glutathione or reduced glutathione content in cells when grown under medium light irradiation at the three temperature (Fig. 6a, b).

\section{Antioxidant Enzyme Activity}

\section{CAT Activity}

CAT activity was significantly $(p<0.05)$ higher in cells when grown with high nitrogen under any levels of light and temperature relative to cells grown with low nitrogen under the same light and temperature. Though the variation of temperature did not have significant effect on CAT activity in cells grown with high nitrogen concentration under high light irradiation, activity was significantly $(p<0.05)$ higher when cells were cultured with high nitrogen at $10{ }^{\circ} \mathrm{C}$ under low light irradiation relative to cells grown at $30{ }^{\circ} \mathrm{C}$ under the same light and nitrogen levels. A threeway ANOVA illustrates that light intensity $(p<0.001)$ and nitrogen concentration $(p<0.001)$ have a significant effect on CAT activity in cultivated cells. However, the effect of temperature $(p=0.053)$ was not significant. The interactions of light $\times$ temperature, light $\times$ nitrogen, temperature $\times$ nitrogen, light $\times$ temperature $\times$ nitrogen all have a significant $(p<0.001)$ effect on CAT activity. CAT activity increased with a decrease in light irradiation at all three temperatures tested (Fig. 7a). Maximum CAT activity $\left(17.75 \pm 1.56 \mathrm{U} \mathrm{mg}^{-1}\right.$ protein) was achieved when cells were grown with high nitrogen at $10{ }^{\circ} \mathrm{C}$ under low light irradiation (Fig. 7a).
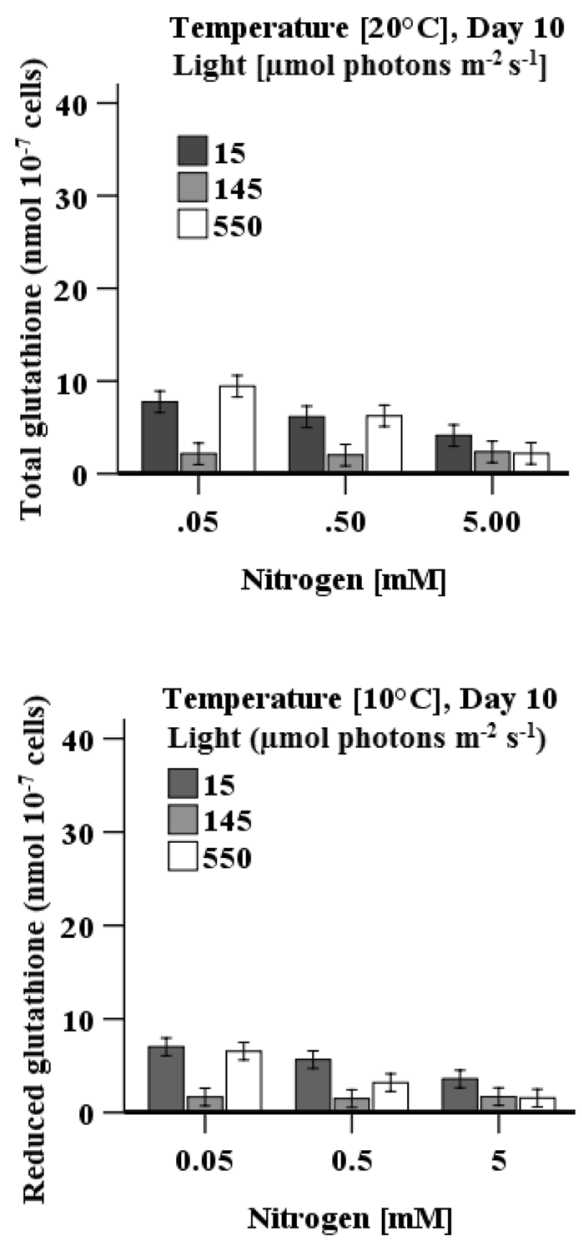

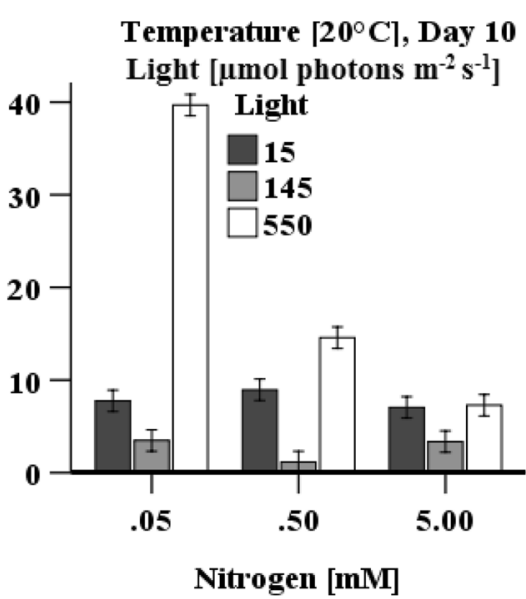

(a)

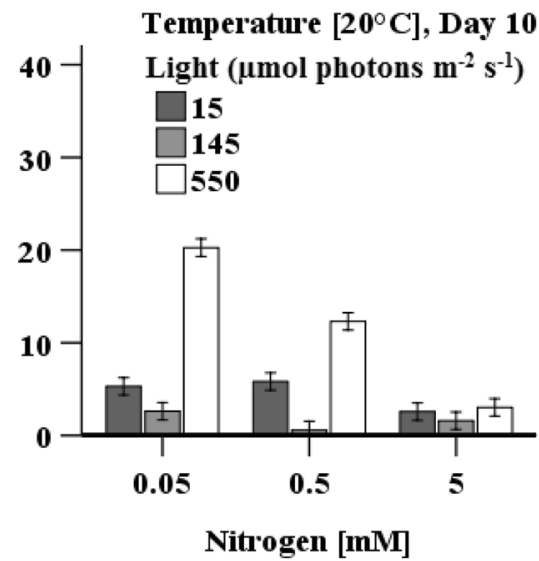

(b)
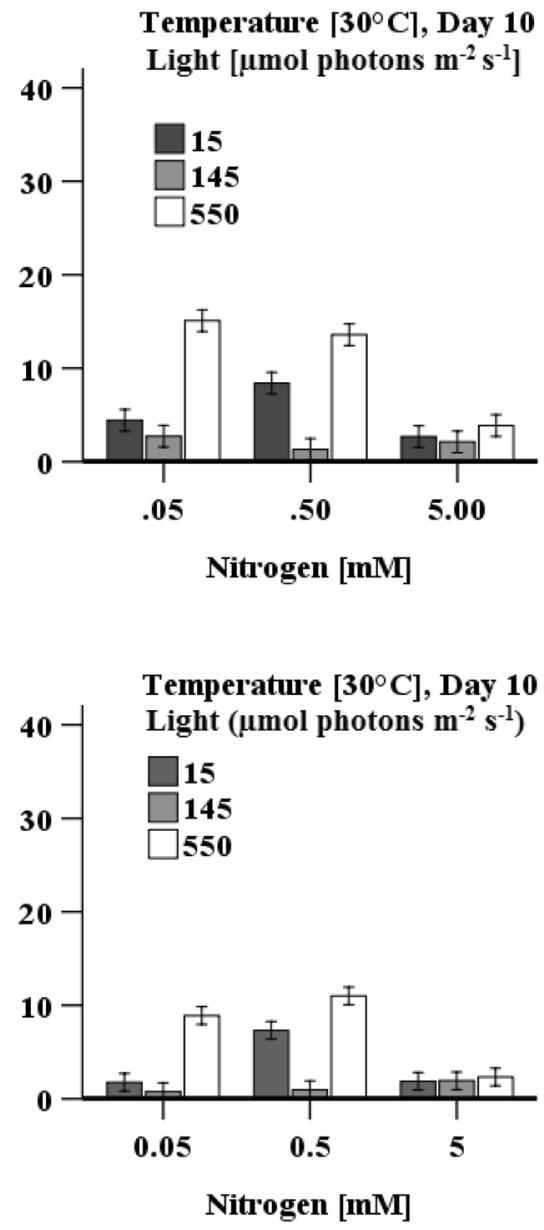

Fig. 6 Effect of light, temperature, and nitrogen levels on a accumulation of total glutathione and $\mathbf{b}$ reduced glutathione content in D. tertiolecta cultures. Data is presented as mean $\pm \operatorname{SE}(n=3)$ 


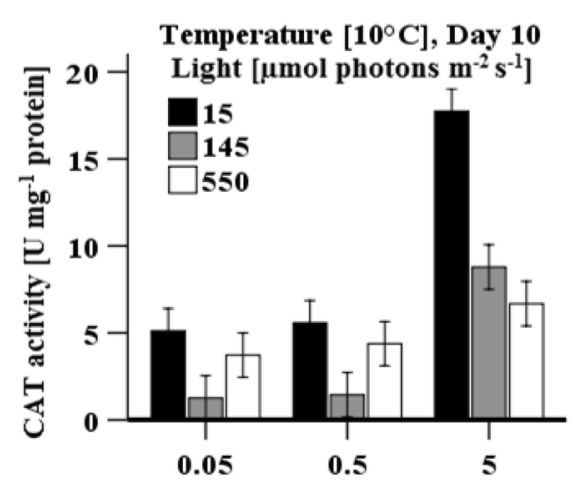

Nitrogen [mM]
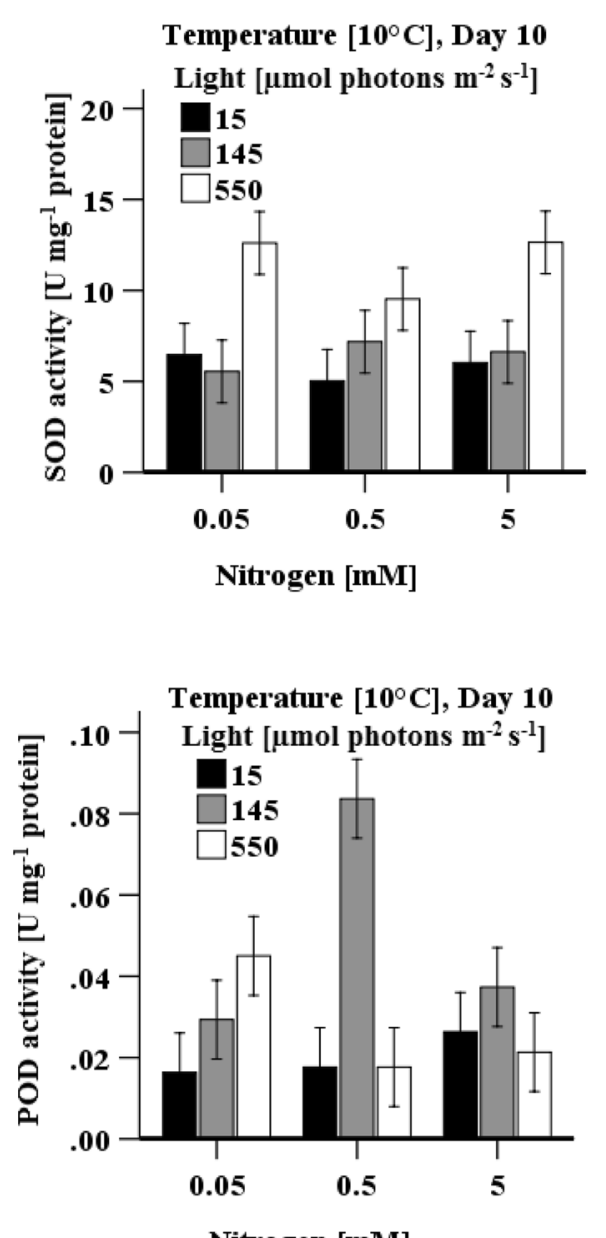

Nitrogen [mM]

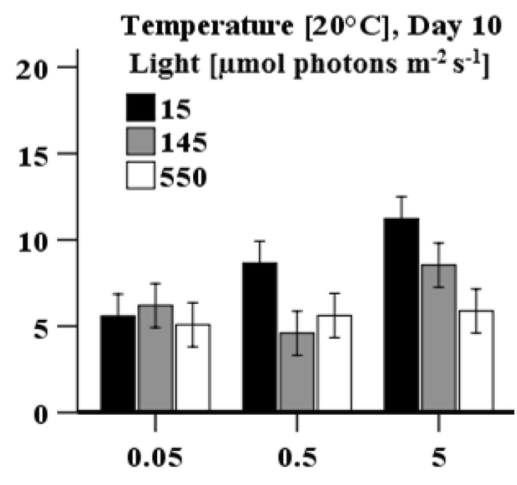

Nitrogen [mM]

(a)

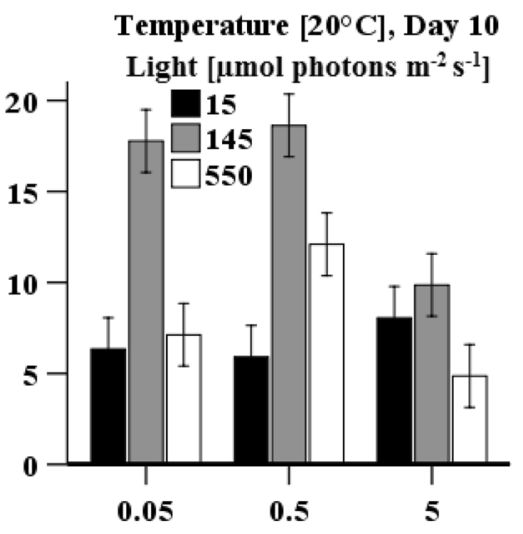

Nitrogen [mM]

(b)

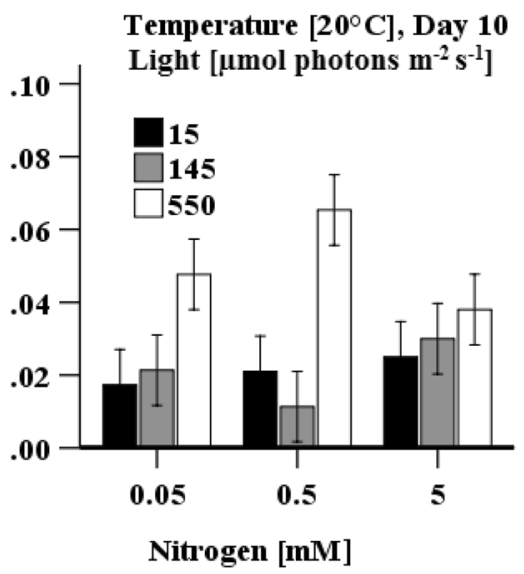

(c)

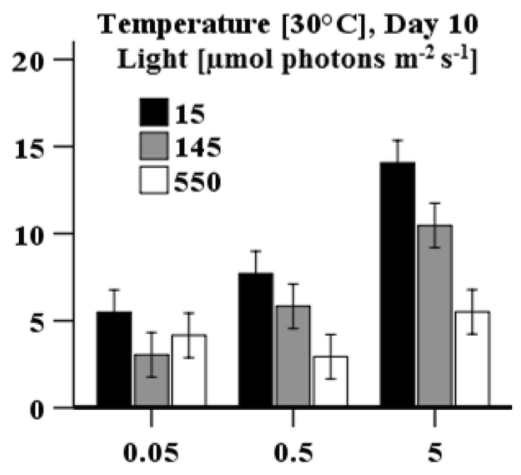

Nitrogen [mM]

Temperature $\left[30^{\circ} \mathrm{C}\right]$, Day 10

Light [ $\mu \mathrm{mol}$ photons $\mathrm{m}^{-2} \mathrm{~s}^{-1}$ ]

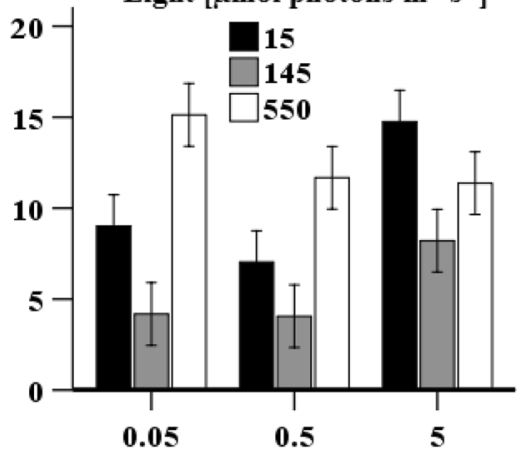

Nitrogen [mM]

Temperature $\left[30^{\circ} \mathrm{C}\right]$, Day 10

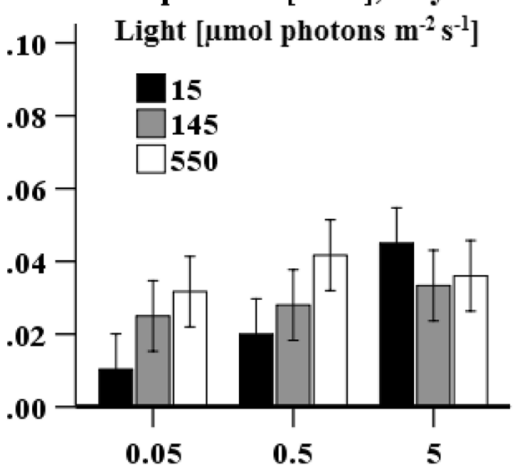

Nitrogen [mM]

Fig. 7 Effect of light, temperature, and nitrogen levels on a CAT activity, b SOD activity, and $\mathbf{c}$ POD activity in D. tertiolecta culture. Data is presented as mean $\pm \operatorname{SE}(n=3)$. Bars show standard error, predicted from ANOVA mode 


\section{SOD Activity}

A three-way ANOVA indicates that light intensity and temperature $(p<0.001)$ significantly affect SOD activity in cells. However, nitrogen concentration is not statistically $(p=0.080)$ significant. The interactions of light $\times$ temperature, light $\times$ nitrogen, temperature $\times$ nitrogen, and light $\times$ temperature $\times$ nitrogen all have significant $(p<0.001)$ effect on SOD activity in cells cultivated for 10 days. Indeed, at $10{ }^{\circ} \mathrm{C}$, increases in both light and nitrogen levels resulted in an increased SOD activity, although not at $145 \mu \mathrm{mol}$ photons $\mathrm{m}^{-2} \mathrm{~s}^{-1}, 0.05 \mathrm{mM} \mathrm{KNO}_{3}$ at $10^{\circ} \mathrm{C}$. In contrast, at $20^{\circ} \mathrm{C}$, the same effect was seen under all conditions, with a sharp increase in activity at medium light irradiation. Similarly, identical effect was observed at $30{ }^{\circ} \mathrm{C}$ under all conditions, with the highest activity at the highest light irradiation (Fig. 7b). Significantly $(p<0.05)$, the highest SOD activity $(17.77 \pm 2.63$ $\mathrm{U} \mathrm{mg}^{-1}$ protein) was observed when cells were grown with low or medium nitrogen $\left(0.05-0.5 \mathrm{mM} \mathrm{KNO}_{3}\right)$ at $20^{\circ} \mathrm{C}$ under light irradiation of $145 \mu \mathrm{mol}$ photons $\mathrm{m}^{-2} \mathrm{~s}^{-1}$ compared to all combination of light, temperature, and nitrogen concentration.

\section{POD Activity}

POD activity increased with light irradiation when cells were grown at all three temperatures and with all three nitrogen levels except when cells were cultured with $0.5 \mathrm{mM} \mathrm{KNO}_{3}$ at low temperature under medium light irradiation (Fig. 7c). Cells cultured with $0.5 \mathrm{mM} \mathrm{KNO}_{3}$ at $10{ }^{\circ} \mathrm{C}$ under medium light resulted in maximum POD activity $(0.084 \pm 0.011 \mathrm{U}$ $\mathrm{mg}^{-1}$ protein). A three-way ANOVA indicates that light intensity $(p<0.001)$ and nitrogen concentration $(p=0.01)$ are significantly affecting POD activity in cells. However, temperature $(p=0.050)$ is not statistically significant. The interactions of light $\times$ temperature $(p<0.001)$, light $\times$ nitrogen $(p<0.001)$, temperature $\times$ nitrogen $(p=0.007)$, and light $\times$ temperature $\times$ nitrogen $(p<0.001)$ all have a significant effect on POD activity. POD activity decreased with increase in nitrogen concentration in cells when cultured under high light irradiation, but the opposite scenario was observed when cells were grown under low light irradiation at the same temperature (Fig. 7c). Significantly $(p<0.05)$ higher POD activity was observed when cells were grown with low nitrogen $\left(<0.5 \mathrm{mM} \mathrm{KNO}_{3}\right)$ at 10 or $20^{\circ} \mathrm{C}$ under high light irradiation $\left(550 \mu \mathrm{mol}\right.$ photons $\left.\mathrm{m}^{-2} \mathrm{~s}^{-1}\right)$ relative to cells grown with high nitrogen under the same light and temperature. Though POD activity did not significantly change with the variation of nitrogen concentrations when cells cultured at $30^{\circ} \mathrm{C}$ under $>145 \mu$ mol photons $\mathrm{m}^{-2} \mathrm{~s}^{-1}$, it was significantly $(p<0.05)$ higher in cells grown with high nitrogen under low light irradiation relative to cells cultured with limited nitrogen $\left(<0.5 \mathrm{mM} \mathrm{KNO}_{3}\right)$ under the same temperature and light irradiation (Fig. 7c).
From the above SPSS (data analysis), optimal level of factors cannot be selected to obtain the highest level of antioxidant content; therefore, design of experiments (Minitab Statistical Software) was further used. Design of experiments (Minitab Statistical Software) predicted the best combination of culturing factors levels for the highest accumulation of enzymatic and non-enzymatic antioxidants in Dunaliella tertiolecta are shown in Table 2.

\section{Discussion}

The combined effect of light, temperature, and nitrogen levels in the cultivation medium was used to induce stress, and both enzymatic and non-enzymatic antioxidant levels in D. tertiolecta were quantified. For the development of a deeper understanding of the overall intracellular antioxidant response, the accumulation of chlorophyll and carotenoid content, cell density, total protein, $\mathrm{H}_{2} \mathrm{O}_{2}$, and MDA content were also quantified. SOD provides the first-line defence against toxic effects of ROS by catalysing the dismutation of $\mathrm{O}_{2}{ }^{--}$to $\mathrm{H}_{2} \mathrm{O}_{2}$ and $\mathrm{O}_{2}$. CAT directly converts $\mathrm{H}_{2} \mathrm{O}_{2}$ into $\mathrm{H}_{2} \mathrm{O}$ and $\mathrm{O}_{2}$, whereas POD scavenges $\mathrm{H}_{2} \mathrm{O}_{2}$ by utilising ascorbate or glutathione as an electron donor (Chokshi et al. 2017).

Predictably, cells grown at both high nitrogen under medium to high light irradiation exhibited highest cell density (Fig. 1a), whilst less antioxidant activity were detected in cells grown with both high light and high nitrogen (Figs. 5 and 6). At high light irradiation, the chloroplastic pigments of the cell will more efficiently absorb energy, which enhances the conversion rate of chemical energy into photochemical reactions (Gu et al. 2014) resulting in a higher growth rate. The observed lower cell density at a low nitrogen level $(0.05 \mathrm{mM})$ and low temperature might be due to the reduction of nutrient assimilation (Ras et al. 2013), lower production of chlorophyll and chloroplastic proteins (Fig. 1b), which in turn decreases the cells light absorption capacity (Benavente-valdes et al. 2016) resulting in a lower the growth rate and the generation of oxidative stress. Therefore, lower antioxidant production and maximum biomass can be obtained in D. tertiolecta cultures, when cells are grown at $20{ }^{\circ} \mathrm{C}$ under $145 \mu \mathrm{mol}$ photons $\mathrm{m}^{-2} \mathrm{~s}^{-1}$ or higher in the presence of high nitrogen concentration $(5 \mathrm{mM}$ $\mathrm{KNO}_{3}$ ), which would be the optimal growth conditions. This result is in agreement with the study of Wu et al. (2016), who reported a temperature of $20^{\circ} \mathrm{C}$ and light irradiation of $135 \mu \mathrm{mol}$ photons $\mathrm{m}^{-2} \mathrm{~s}^{-1}$ for optimal $D$. salina growth.

Total protein content also substantially increased at high nitrogen concentration in all combinations of factors (Fig. 2), as nitrogen is essential for the formation of structural and functional peptides, proteins and enzymes (Cai et al. 2013). A positive correlation between nitrogen concentration and protein accumulation in three Chlorella strains was reported 
Table 2 DoE optimised best combination of culturing factors compared with literature reported levels of antioxidant components

\begin{tabular}{|c|c|c|c|c|c|}
\hline \multicolumn{3}{|c|}{$\begin{array}{l}\text { Intracellular components in } D \text {. tertiolecta in response to variation of } \\
\text { light, temperature, and nitrogen concentration during cultivation (this } \\
\text { study) }\end{array}$} & \multicolumn{3}{|c|}{$\begin{array}{l}\text { Intracellular components in Dunaliella in response to variation of } \\
\text { light, temperature, and nitrogen concentration during cultivation }\end{array}$} \\
\hline Compounds & Optimal levels & $\begin{array}{l}\text { Response } \\
\text { (maximum } \\
\text { production) }\end{array}$ & Compounds & Culture conditions & Reference \\
\hline \multirow{8}{*}{$\begin{array}{l}\text { Chlorophyll ( } \mu \mathrm{g} 10^{-7} \\
\text { cells) }\end{array}$} & \multirow[t]{8}{*}{$\mathrm{L}(15)+\mathrm{T}(20)+\mathrm{N}(5)$} & \multirow[t]{8}{*}{64.28} & $36.5 \pm 6.1$ & $\mathrm{~L}(200)+\mathrm{T}(25)$ & (Xu et al. 2016) \\
\hline & & & 16 & $\mathrm{~L}(100)+\mathrm{T}(28)$ & (Haghjou et al. 2009) \\
\hline & & & 7 & $\mathrm{~L}(100)+\mathrm{T}(28)$ & \\
\hline & & & 14.28 & $\mathrm{~T}(28)+\mathrm{N}(250)$ & (Singh et al. 2016) \\
\hline & & & 20.45 & $\mathrm{~T}(37)+\mathrm{N}(0.75)$ & \\
\hline & & & 20 & $\mathrm{~L}(190)+\mathrm{N}(5)$ & $\begin{array}{l}\text { (Gallego-Cartagena et al. } \\
\text { 2019) }\end{array}$ \\
\hline & & & $70 \pm 11$ & $\begin{array}{l}\mathrm{L}(60)+(\mathrm{N}+\mathrm{S}) \text { (starva- } \\
\text { tion) }\end{array}$ & (Lv et al. 2016) \\
\hline & & & 100 & $\mathrm{~L}(68)+\mathrm{T}(22-30)$ & (Wu et al. 2016) \\
\hline \multirow[t]{6}{*}{ Carotenoid ( $\mu \mathrm{g} 10^{-7}$ cells) } & \multirow[t]{6}{*}{$\mathrm{L}(15)+\mathrm{T}(20)+\mathrm{N}(5)$} & \multirow[t]{6}{*}{10.49} & $8.1 \pm 1.1$ & $\mathrm{~L}(50)+\mathrm{T}(25)$ & (Xu et al. 2016) \\
\hline & & & 6.8 & $\mathrm{~T}(37)+\mathrm{N}(0.75)$ & (Singh et al. 2016) \\
\hline & & & 3.5 & $\mathrm{~T}(28)+\mathrm{N}(250)$ & \\
\hline & & & 10 & $\mathrm{~L}(190)+\mathrm{N}(5)$ & (Gallego-Cartagena et al. \\
\hline & & & 29 & $\begin{array}{l}\mathrm{L}(390)+\mathrm{N}(0.5)+\mathrm{NaCl} \\
\quad(4 \mathrm{M})\end{array}$ & 2019) \\
\hline & & & 250 & $\mathrm{~L}(800)$ & (Nguyen et al. 2016) \\
\hline \multirow{4}{*}{$\begin{array}{l}\text { Total protein content ( } \mathrm{mg} \\
10^{-7} \text { cells) }\end{array}$} & \multirow[t]{4}{*}{$\mathrm{L}(15)+\mathrm{T}(10)+\mathrm{N}(5)$} & \multirow[t]{4}{*}{1.40} & $0.266 \pm 0.04$ & $\mathrm{~L}(1000)+\mathrm{T}(25)$ & (Xu et al. 2016) \\
\hline & & & $0.62 \pm 0.12$ & $\mathrm{~L}(150)+\mathrm{N}(5)$ & (Yilancioglu et al. 2014) \\
\hline & & & 0.10 & $\mathrm{~L}(100)+\mathrm{T}(28)$ & (Haghjou et al. 2009) \\
\hline & & & 0.27 & $\mathrm{~L}(100)+\mathrm{T}(28)$ & \\
\hline \multicolumn{6}{|l|}{ Non-enzymatic antioxidant } \\
\hline $\begin{array}{l}\text { Phenolic compounds ( } \mu \mathrm{g} \\
\text { GAE } 10^{-7} \text { cells) }\end{array}$ & $\mathrm{L}(15)+\mathrm{T}(20)+\mathrm{N}(0.5)$ & 39.59 & & & \\
\hline \multirow{2}{*}{$\begin{array}{l}\text { Total ascorbate (nmol } \\
10^{-7} \text { cells) }\end{array}$} & \multirow[t]{2}{*}{$\mathrm{L}(550)+\mathrm{T}(20)+\mathrm{N}(0.5)$} & \multirow[t]{2}{*}{200} & 18 & $\mathrm{~L}(100)+\mathrm{T}(13)$ & \multirow[t]{2}{*}{ (Haghjou et al. 2009) } \\
\hline & & & 14 & $\mathrm{~L}(1200)+\mathrm{T}(28)$ & \\
\hline \multirow{2}{*}{$\begin{array}{l}\text { Total glutathione ( } \mathrm{nmol} \\
10^{-7} \text { cells) }\end{array}$} & \multirow{2}{*}{$\begin{array}{l}\mathrm{L}(550)+\mathrm{T}(20)+\mathrm{N} \\
\quad(0.05)\end{array}$} & \multirow[t]{2}{*}{39.67} & 3 & $\mathrm{~L}(1200)+\mathrm{T}(13)$ & \multirow[t]{2}{*}{ (Haghjou et al. 2009) } \\
\hline & & & 2 & $\mathrm{~L}(1200)+\mathrm{T}(13)$ & \\
\hline \multicolumn{6}{|l|}{ Enzymatic antioxidant } \\
\hline \multirow{4}{*}{$\begin{array}{l}\text { CAT activity }\left(\mathrm{U} \mathrm{mg}^{-1}\right. \\
\text { protein) }\end{array}$} & \multirow[t]{4}{*}{$\mathrm{L}(15)+\mathrm{T}(\mathrm{NS})+\mathrm{N}(5)$} & \multirow[t]{4}{*}{14.34} & $6.67 \pm 0.89$ & $\mathrm{~L}(150)+3 \mathrm{M} \mathrm{NaCl}$ & (Jahnke and White 2003) \\
\hline & & & $0.12 \pm 0.01$ & $\mathrm{~L}(150)+\mathrm{N}(5)$ & (Yilancioglu et al. 2014) \\
\hline & & & 20.13 & $\mathrm{UV}+\mathrm{N}$ (optimum) & (Tian and Yu 2009) \\
\hline & & & 31.45 & $16 \% \mathrm{NaCl}+\mathrm{N}(5)$ & \\
\hline \multirow{5}{*}{$\begin{array}{l}\text { SOD activity }\left(\mathrm{U} \mathrm{mg}^{-1}\right. \\
\text { protein) }\end{array}$} & \multirow[t]{5}{*}{$\mathrm{L}(145)+\mathrm{T}(20)+\mathrm{N}(\mathrm{NS})$} & \multirow[t]{5}{*}{15.19} & $24.8 \pm 2.63$ & UV + N (optimum) & (Al-Rashed et al. 2016) \\
\hline & & & $14.25 \pm 0.45$ & UV + N (Starvation) & \\
\hline & & & 20.36 & UV + N (optimum) & (Tian and Yu 2009) \\
\hline & & & 33.61 & $2.8 \mathrm{M} \mathrm{NaCl}+\mathrm{N}(5)$ & \\
\hline & & & $0.625 \pm 0.09$ & $\mathrm{~L}(150)+3 \mathrm{M} \mathrm{NaCl}$ & (Jahnke and White 2003) \\
\hline $\begin{array}{l}\text { POD activity }\left(\mathrm{U} \mathrm{mg}^{-1}\right. \\
\text { protein) }\end{array}$ & $\mathrm{L}(145)+\mathrm{T}(10)+\mathrm{N}(0.5)$ & 0.083 & & & \\
\hline
\end{tabular}

Symbol L, T, N, NS indicate the light, temperature, nitrogen levels, and not significant, respectively. The unit of light is presented as $\mu$ mol photons $\mathrm{m}^{-2} \mathrm{~s}^{-1}$, temperature as ${ }^{\circ} \mathrm{C}$, and nitrogen level as $\mathrm{mM} \mathrm{KNO}_{3}$

in the study by Ordog et al. (2016), which is in agreement with the result presented here. During nitrogen starvation, carbon flow is directed from protein synthesis to fatty acid and carbohydrate synthesis (Yilancioglu et al. 2014); causing a reduced protein production (Fig. 2). Moreover, during nitrogen deprivation proteins may degrade to sustain 
short-term growth, resulting in decreased protein content (Ördög et al. 2016). The result (Fig. 2 and Table 2) indicates that low temperature along with low light culture conditions are favourable for protein accumulation in D. tertiolecta, which may be due to carbon from polysaccharides, chlorophyll a, and photosynthate incorporated to protein synthesis (Rivkin 1989). The low chlorophyll content (per cell) (Fig. 1b) in cells cultivated at low temperature with low light irradiation indicates that chlorophyll may be involve in the synthesis of protein. Thompson et al. (1992) also reported an increased protein accumulation in $D$. tertiolecta as the temperature dropped from 15 to $10^{\circ} \mathrm{C}$. Similarly, higher protein content was reported in P. tricornutum when growth temperature reduced from 18 to $7{ }^{\circ} \mathrm{C}$. Since antioxidant enzymes (CAT, POD, and SOD) are proteinous molecules, it is expected that these enzymes will be stimulated with the changes of culture conditions.

The highest CAT activity was found in cells when grown with high nitrogen under low light irradiation, whilst POD activity was maximum under medium light irradiation (Fig. 7a, c and Table 2). Nitrogen availability increases the rate of photosynthesis and the number of electrons transported through the Z-scheme electron pathway ( $\mathrm{Li}$ et al. 2016), which further increases the photorespiration rate and other metabolism and produces $\mathrm{H}_{2} \mathrm{O}_{2}$ (Zervoudakis et al. 2015) resulting in an increased level of CAT activity. The low $\mathrm{H}_{2} \mathrm{O}_{2}$ content in cells grown with high nitrogen at low temperature and under low light irradiation (Fig. 3a) could indicate maximum detoxification of $\mathrm{H}_{2} \mathrm{O}_{2}$ (highest stimulation of CAT activity). The predomination of CAT in eliminating $\mathrm{H}_{2} \mathrm{O}_{2}$ at low temperature may decrease POD response (Chokshi et al. 2017) as CAT has a high turnover rate (one molecule can convert 6 million $\mathrm{H}_{2} \mathrm{O}_{2}$ to $\mathrm{H}_{2} \mathrm{O}$ and $\mathrm{O}_{2}$ within one minute) (Gill and Tuteja 2010). Low light irradiation reduces the rate of carbon assimilation and the photosynthetic apparatus is rearranged in order to increase light absorption efficiency, which diverts carbon metabolism from lipid biosynthesis toward the synthesis of the light-harvesting antenna protein complexes (Falkowski et al. 1981; Sukenik et al. 1990). This unbalanced C-N metabolism produces oxidative stress (Zhang et al. 2010), stimulating CAT activity.

The accumulation of $\mathrm{H}_{2} \mathrm{O}_{2}$ and MDA content differs in response to variation in light, temperature, and nitrogen concentration during cultivation of D. tertiolecta (Fig. 3a, b). These components are all used as oxidative stress markers (Chokshi et al. 2017; Zhu et al. 2017). The highest $\mathrm{H}_{2} \mathrm{O}_{2}$ content simultaneous with the highest CAT and POD activity, and the lowest MDA content together with the highest SOD activity at high temperature when cells grown with high nitrogen and low light irradiation (Table 2) demonstrate that oxidative stress is eliminated by SOD by converting $\mathrm{O}_{2}{ }^{-}$. into $\mathrm{H}_{2} \mathrm{O}_{2}$, which further is reduced by both CAT and POD (Figs. 3 and 7). A decrease in the reduced form of ascorbate and glutathione also indicates the use of these components as a substrate (Sharma et al. 2012) in the peroxidase reaction processes (Figs. 5 and 6). Accumulated reduced ascorbate and glutathione content in cells grown under low light irradiation indicated that these components act as antioxidants to prevent cells damage from the oxidation stress generated by low light (Fig. 5). The higher ratio of ASc:DASc in cells indicate the enhancement of the reduced form of ascorbate, which occur not only at the expense of its oxidised form (DASc) reduction but also due to de novo molecule synthesis (biosynthesis from different molecules) (Radyuk et al. 2009). Accumulation of pigments (chlorophyll and carotenoid) was highest in $D$. tertiolecta cells when grown under low light irradiation accompany with high nitrogen concentration (Fig. 1a-c and Table 2), which suggest that these are involved in protecting cells from low light-induced oxidative stress. The chlorophyll content is directly linked to the cells photosynthetic capacity (Zhu et al. 2017). In contrast, carotenoids protect cells from photodamage by scavenging singlet oxygen and other reactive oxygen species and by absorbing heat (Yilancioglu et al. 2014); therefore, to maximise light energy absorption at low light irradiation, pigment content increases (Beneragama and Goto 2010; Robinson et al. 1995).

Though CAT activity was found to be at its highest when cells were grown with high nitrogen, POD and SOD activity substantially increased at limited nitrogen concentration and high light irradiation $\left(\geq 145 \mu \mathrm{mol}\right.$ photons $\left.\mathrm{m}^{-2} \mathrm{~s}^{-1}\right)$, which indicates that POD and SOD activity is highly responsive to high light irradiation and low nitrogen. Accumulation of $\mathrm{H}_{2} \mathrm{O}_{2}$ and MDA content (Fig. 3a, b) simultaneous with higher POD and SOD activity at low temperature when cells were grown under high light irradiation demonstrates that oxidative stress was mitigated by POD combined with SOD. High light may cause overexpression of the SOD gene (FeSOD) in D. salina (Park et al. 2006), and may bring about an increased flow of electrons in the electron transport chains of the photosystem, thereby leaking more electrons onto $\mathrm{O}_{2}$, generating superoxide ion $\left(\mathrm{O}_{2}^{-\cdot}\right)$. Cells grown with nitrogen concentration $\left(\leq 0.5 \mathrm{mM} \mathrm{KNO}_{3}\right)$ under high light irradiation also enhanced the accumulation of total glutathione and total ascorbate content (Fig. 5), which may be a way to mitigate high light and low nitrogen-induced oxidative stress (Wang et al. 2010). An increased level of reduced ascorbate content under high light coupled with nitrogen level $\left(0.5 \mathrm{mM} \mathrm{KNO}_{3}\right)$ indicates the role of ascorbate as a cofactor of violaxanthin de-epoxidase, thus, sustaining dissipation of excess excitation energy and may directly react with $\operatorname{ROS}\left(\mathrm{O}_{2}{ }^{-{ }^{-}}, \mathrm{H}_{2} \mathrm{O}_{2}\right)$ to protect against cell damage (Sharma et al. 2012). The findings presented here are in agreement with the results of Haghjou et al. (2009), who observed increased glutathione, ascorbate, SOD and POD activity in D. salina when these cells were grown at low temperature under high light irradiation 
(Table 2). Similarly, an increased glutathione content with increases in light irradiance levels was observed in an endosymbiotic dinoflagellate (Symbiodinium) (Muhaemin et al. 2017), which is also consistent to the findings presented here. In addition, the result is in line with the investigation of El-Baky et al. (2004), who obtained high POD and SOD activity as well as high total glutathione and ascorbate content in limited nitrogen cultures of $D$. salina under high light irradiation. Al-rashed et al. (2016) and Lv et al. (2016) also reported that D. salina subjected to nitrogen starvation-induced oxidative stress increased SOD activity. Compared to low light, chlorophyll and carotenoid content were reduced under high light (Fig. 1b, c), which may be due to damage of the photosystems centre (PSII) and reduced levels of the light-harvesting apoproteins in the chloroplast thylakoids in the cells (Neidhardt et al. 1998; Sukenik et al. 1990). However, high cell density was found when the cultures were grown with high nitrogen levels under high light irradiation, which may be due to this algae's efficient repair cycle that allows it to replace damaged PSII at a much faster rate to maintain maximum photosynthetic efficiency $(\mathrm{Gu}$ et al. 2014; Xu et al. 2016). A study of Xu et al. (2016) reported an increase in optical density with a decreased chlorophyll and carotenoid content in D. tertiolecta under high light irradiation, which is consistent to the presented finding.

Compared to cells grown at $20{ }^{\circ} \mathrm{C}$ with low nitrogen under low light irradiation, the accumulation of MDA and SOD activity in cells when grown under high light irradiation with the same temperature and nitrogen indicates the inversely proportional relationship of MDA to SOD; SOD could not eliminate superoxide radicals from the cells. Therefore, glutathione or ascorbate participated in protecting cells from high light and low nitrogen-induced stress. Total phenolic content was found to be its highest when cells grown at $20^{\circ} \mathrm{C}$ with low nitrogen and low light irradiation (Fig. $2 \mathrm{~b}$ and Table 2) demonstrating that phenolic compounds take part in mitigating low nitrogen and low light-induced stress (Ismaiel 2016) and act as an antioxidant. Phenolic biosynthesis could occur as an alternative pathway for photochemical energy dissipation enabled to enhance the antioxidant capacity of the cell (Grace and Logan 2000) under stress conditions, whilst carbon flow in the phenolic biosynthesis is usually through the phenylpropanoid pathway (Kepekci and Saygideger 2012) during optimal growth condition. The result is in agreement with a study by Aremu et al. (2015), who demonstrated that moderate nitrogen concentration promoted phenolic content in Chlorella minutissima (Aremu et al. 2015). A study by Kepekci and Saygideger (2012) reported the lowest phenolic content in Spirulina platensis cells when cultured at $30^{\circ} \mathrm{C}$ under $40 \mu \mathrm{mol}$ photons $\mathrm{m}^{-2} \mathrm{~s}^{-1}$, whilst the highest amount was found in the cultures incubated under $120 \mu \mathrm{mol}$ photons $\mathrm{m}^{-2} \mathrm{~s}^{-1}$, which is opposite to the findings presented here. This might be due to variability between strains. A study of Al-Rashed et al. (2016) reported that nitrogen deprivation
Fig. 8 Visual presentation of the effect of light, temperature, and nitrogen levels on cellular antioxidant system in D. tertiolecta (represented by $\mathrm{L}, \mathrm{T}$, and $\mathrm{N}$, respectively). LL, 15; ML, 145; HL, $550 \mu \mathrm{mol}$ photons $\mathrm{m}^{-2} \mathrm{~s}^{-1}$; LT, 10; MT, 20; HT, $30{ }^{\circ} \mathrm{C}$; LN, 0.05; MN, 0.5; HN, $5 \mathrm{mM}$ )

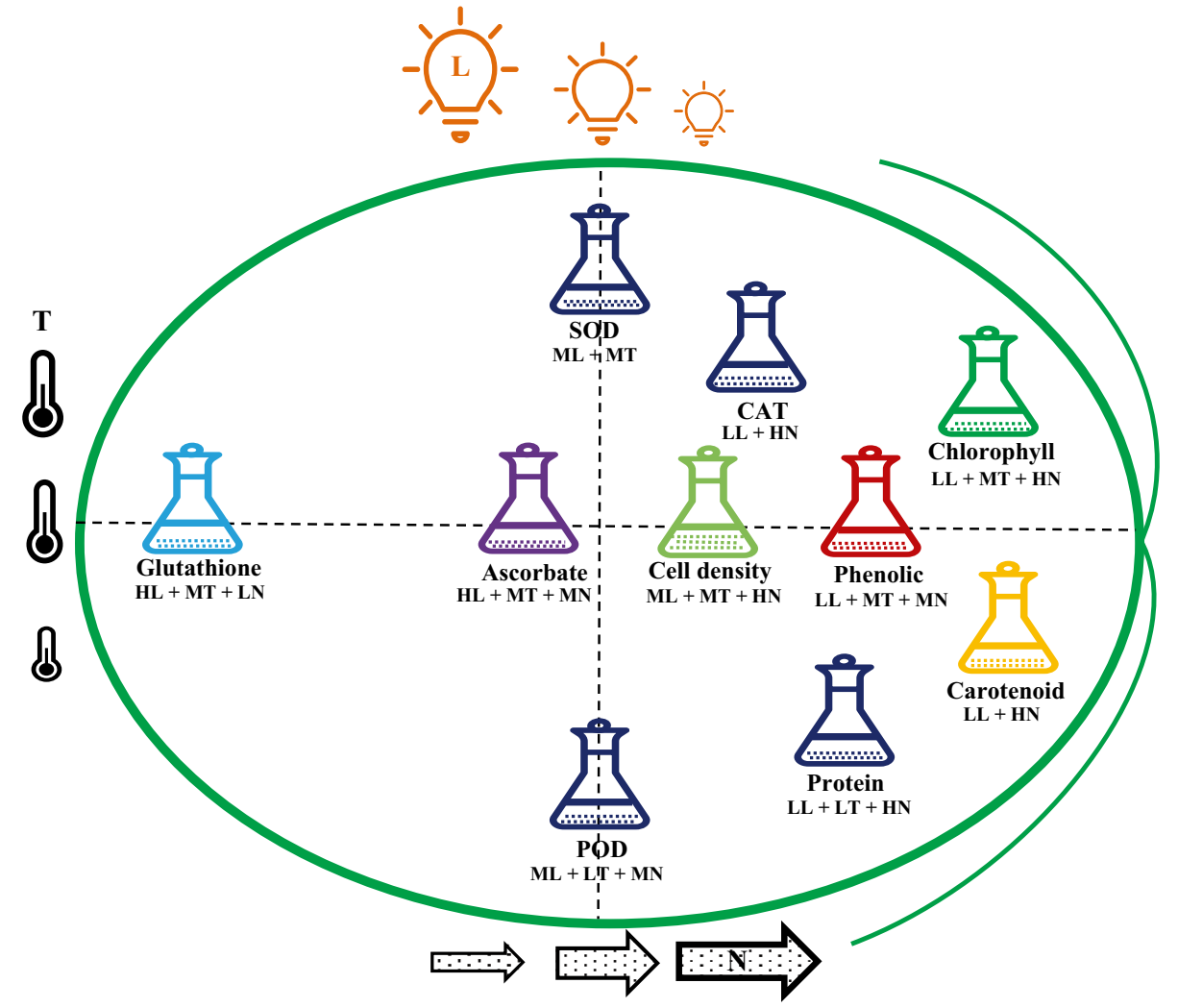


enhanced total phenolic in two strains (D. salina and Spirulina platensis), which is consistent with this study. As there are limited studies available on the accumulation of phenolic compounds by microalgae, more research is still needed to determine how phenolic content responds to the accumulation of ROS in different microalgae under various stress conditions.

As limited nitrogen availability under low light irradiation in cultures stimulated ascorbate, glutathione, and phenolic contents, these components collectively mitigate low light and low nitrogen-induced oxidative stress. Nitrogen and temperature did not have a significant impact on the accumulation of phenolic compounds when cells were grown at medium light irradiation $\left(145 \mu \mathrm{mol}\right.$ photons $\left.\mathrm{m}^{-2} \mathrm{~s}^{-1}\right)$. However, glutathione content was the lowest in cells when grown under medium light irradiation together with all combinations of nitrogen and temperatures indicating that glutathione may directly scavenge free radical $\left(\mathrm{O}_{2}{ }^{\bullet-},{ }^{\bullet} \mathrm{OH}\right.$, $\mathrm{H}_{2} \mathrm{O}_{2}$ ) or can participate in the regeneration of another potential antioxidant ASc, via the ASc-GSH cycle (Sharma et al. 2012). The highest POD activity (Table 2) and the lowest ascorbate levels were found in cells when grown at low temperature with moderate nitrogen $\left(0.5 \mathrm{mM} \mathrm{KNO}_{3}\right)$ under medium light irradiation which indicates the predomination of POD to minimise $\mathrm{H}_{2} \mathrm{O}_{2}$ content relative to CAT. This result is consistent with a study by Haghjou et al. (2006), who reported high POD activity at $13{ }^{\circ} \mathrm{C}$ under light irradiation $\left(100 \mu \mathrm{mol}\right.$ photons $\left.\mathrm{m}^{-2} \mathrm{~s}^{-1}\right)$ in $D$. salina cell cultures.

Both chlorophyll and carotenoids achieved their highest level in cells when grown at a medium temperature under low light irradiation and high nitrogen levels (Table 2). Protein content and CAT activity are both highly responsive to stress induced by low light irradiation combined with a high nitrogen content with temperature also being significant for protein content. Total phenolic content was found to be highest when cells were grown with medium nitrogen at medium temperature and low light irradiation. Both POD and SOD activities were maximum in cells when grown under the medium light irradiation, but the highest POD activity was found at low temperature with medium level of nitrogen and SOD activity at medium level of nitrogen. Total ascorbate and glutathione content reached its highest levels in D. tertiolecta when cells were grown with limited nitrogen under high light irradiation and medium temperature (Fig. 8 and Table 2).

\section{Conclusion}

In this study, antioxidant responses of $D$. tertiolcta cells exposed to different levels of light, temperature, and nitrogen were investigated. The results demonstrate that high cell density in D. tertiolecta can be obtained in culture when cells were grown with high nitrogen at medium temperature under medium light irradiation. The accumulation of chlorophyll and carotenoid was maximum in cells grown with high nitrogen levels under low light irradiation at a medium temperature. Similarly, maximum total protein and CAT activity were found at the same light and nitrogen levels; however, temperature has no significant impact on CAT activity. The highest phenolic content in D. tertiolecta cells was observed when cells were grown with medium nitrogen level at a medium temperature under low light irradiation. Cells grown with medium nitrogen at a medium temperature under high light irradiation accumulated maximum total ascorbate content. Similarly, total glutathione content was maximum when cells were grown under the same light and temperature, but in the presence of low nitrogen content in the culture. Maximum SOD activity in D. tertiolecta was found when cells were cultured under medium light irradiation at a medium temperature. However, the highest POD activity was achieved in cells grown with medium nitrogen under medium light irradiation at low temperature. Optimal values indicate that a further experiment is warranted as responses possible would increase if conditions are extended beyond this research range or investigated in a narrower range.

These results provide the overall physiological responses, including antioxidant enzymes activity in $D$. tertiolecta cells under three levels of light, temperature, and nitrogen concentration, and indicate a novel strategy to improve the antioxidant production. Also, scientific information obtained from this study on the production of enzymatic and nonenzymatic antioxidants in D. tertiolecta has 'opened the door' to additional possibilities for commercial exploitation.

Acknowledgements The authors would like to thank the members of the Algal Biotechnology group, University of Greenwich, for support during this research.

Author Contribution Uttam Roy participated in the study design, performed the experiments, collected, and analysed data, interpreted the result, and drafted the manuscript. John Milledge and Birthe Nielsen participated in experimental design, data analysis, editing, and critically revised the manuscript. All authors read and approved the final manuscript.

\section{Declarations}

Conflict of Interest The authors declare no competing interests.

Open Access This article is licensed under a Creative Commons Attribution 4.0 International License, which permits use, sharing, adaptation, distribution and reproduction in any medium or format, as long as you give appropriate credit to the original author(s) and the source, provide a link to the Creative Commons licence, and indicate if changes were made. The images or other third party material in this article are included in the article's Creative Commons licence, unless indicated otherwise in a credit line to the material. If material is not included in the article's Creative Commons licence and your intended use is not permitted by statutory regulation or exceeds the permitted use, you will 
need to obtain permission directly from the copyright holder. To view a copy of this licence, visit http://creativecommons.org/licenses/by/4.0/.

\section{References}

Al-Rashed SA, Ibrahim MM, El-Gaaly GA, Al-Shehri S, Mostafa A (2016) Evaluation of radical scavenging system in two microalgae in response to interactive stresses of UV-B radiation and nitrogen starvation. Saudi J Biol Sci 23:706-712

Ambati RR, Gogisetty D, Aswathanarayana RG, Ravi S, Bikkina PN, Bo L, Yuepeng S (2019) Industrial potential of carotenoid pigments from microalgae: current trends and future prospects. Crit Rev Food Sci Nutr 59:1880-1902

Aremu AO, Neményi M, Stirk WA, Ördög V, van Staden J (2015) Manipulation of nitrogen levels and mode of cultivation are viable methods to improve the lipid, fatty acids, phytochemical content, and bioactivities in Chlorella minutissima. J Phycol 51:659-669

Ben-Amotz A, Avron M (1990) The biotechnology of cultivating the halotolerant alga Dunaliella. Trends Biotechnol 8:121-126

Benavente-valdes JR, Aguilar C, Contreras-esquivel JC, Méndez-zavala A, Montañez J (2016) Strategies to enhance the production of photosynthetic pigments and lipids in chlorophycae species. Biotechnol Rep 10:117-125

Beneragama CK, Goto K (2010) Chlorophyll a: b ratio increases under low-light in "shade-tolerant" Euglena gracilis. Trop Agric Res 22:12-25

Brasil BSAF, de Siqueira FG, Salum TFC, Zanette CM, Spier MR (2017) Microalgae and cyanobacteria as enzyme biofactories. Algal Res 25:76-89

Cai T, Park SY, Li Y (2013) Nutrient recovery from wastewater streams by microalgae: Status and prospects. Renew Sustain Energy Rev 19:360-369

Chokshi K, Pancha I, Ghosh A, Mishra S (2017) Nitrogen starvationinduced cellular crosstalk of ROS-scavenging antioxidants and phytohormone enhanced the biofuel potential of green microalga Acutodesmus dimorphus. Biotechnol Biofuels 10:1-12

Cirulis JT, Scott JA, Ross GM (2013) Management of oxidative stress by microalgae. Can J Physiol Pharmacol 91:15-21

El-Baky HHA, El Baz FK, El-Baroty GS (2004) Production of antioxidant by the green alga Dunaliella salina. Int J Agric Biol 6:49-57

Falleh H, Ksouri R, Lucchessi ME, Abdelly C, Magné C (2012) Ultrasound-assisted extraction: Effect of extraction time and solvent power on the levels of polyphenols and antioxidant activity of Mesembryanthemum edule L. Aizoaceae shoots. Trop J Pharm Res 11:243-249

Falkowski PG, Owens TG, Ley AC, Mauzerall DC (1981) Effects of Growth Irradiance Levels on the Ratio of Reaction Centers in Two Species of Marine Phytoplankton. Plant Physiol 68:969-973

Gallego-Cartagena E, Castillo-Ramírez M, Martínez-Burgos W (2019) Effect of stressful conditions on the carotenogenic activity of a Colombian strain of Dunaliella salina. Saudi J Biol Sci 26:1325-1330

Georgianna DR, Hannon MJ, Marcuschi M, Wu S, Botsch K, Lewis AJ, Hyun J, Mendez M, Mayfield SP (2013) Production of recombinant enzymes in the marine alga Dunaliella tertiolecta. Algal Res 2:2-9

Gill SS, Tuteja N (2010) Reactive oxygen species and antioxidant machinery in abiotic stress tolerance in crop plants. Plant Physiol Biochem 48:909-930

Gómez PI, González MA (2005) The effect of temparature and irradiance on the growth and carotenogenic capacity of seven strains of Dunaliella salina (Chlorophyta) cultivated under laboratory conditions. Biol Res 38:151-162
Grace SC, Logan BA (2000) Energy dissipation and radical scavenging by the plant phenylpropanoid pathway. Philos Trans R Soc Lond B Biol Sci 355:1499-1510

Gu W, Li H, Zhao P, Yu R, Pan G, Gao S, Xie X, Huang A, He L, Wang G (2014) Quantitative proteomic analysis of thylakoid from two microalgae (Haematococcus pluvialis and Dunaliella salina) reveals two different high light-responsive strategies. Sci Rep 4:6661

Haghjou MM, Shariati M, Smirnoff N (2009) The effect of acute high light and low temperature stresses on the ascorbate-glutathione cycle and superoxide dismutase activity in two Dunaliella salina strains. Physiol Plant 135:272-280

Haghjou MM, Shariati M, Pozveh MH (2006) The effect of low light intensities on oxidative stress induced by short-term chilling in Dunaliella salina Teod. Pak J Biol Sci 9:2048-2054

Hodges DM, DeLong JM, Forney CF, Prange RK (1999) Improving the thiobarbituric acid-reactive-substances assay for estimating lipid peroxidation in plant tissues containing anthocyanin and other interfering compounds. Planta 207:604-611

Ismaiel MMS (2016) Effect of nitrogen regime on antioxidant parameters of selected prokaryotic and eukaryotic microalgal species. Acta Physiol Plant 38:1-12

Jagota SK, Dani HM (1982) A new colorimetric technique for the estimation of vitamin $\mathrm{C}$ using Folin phenol reagent. Anal Biochem 127:178-182

Jahnke LS, White AL (2003) Long-term hyposaline and hypersaline stresses produce distinct antioxidant responses in the marine alga Dunaliella tertiolecta. J Plant Physiol 160:1193-1202

Janknegt PJ, De Graaff CM, Van De Poll WH, Visser RJW, Helbling EW, Buma AGJ (2009) Antioxidative responses of two marine microalgae during acclimation to static and fluctuating natural uv radiation. Photochem Photobiol 85:1336-1345

Juneja A, Ceballos RM, Murthy GS (2013) Effects of environmental factors and nutrient availability on the biochemical composition of algae for biofuels production: a review. Energies 6:4607-4638

Junglee S, Urban L, Sallanon H, Lopez-Lauri F (2014) optimized assay for hydrogen peroxide determination in plant tissue using potassium iodide. Am J Anal Chem 5:730-736

Kepekci RA, Saygideger SD (2012) Enhancement of phenolic compound production in Spirulina platensis by two-step batch mode cultivation. J Appl Phycol 24:897-905

Kuda T, Tsunekawa M, Hishi T, Araki Y (2005) Antioxidant properties of dried 'kayamo-nori', a brown alga Scytosiphon lomentaria (Scytosiphonales, Phaeophyceae). Food Chem 89:617-622

Li T, Xu J, Gao B, Xiang W, Li A, Zhang C (2016) Morphology, growth, biochemical composition, and photosynthetic performance of Chlorella vulgaris (Trebouxiophyceae) under low and high nitrogen supplies. Algal Res 16:481-491

Lv H, Cui X, Wahid F, Xia F, Zhong C, Jia S (2016) Analysis of the physiological and molecular responses of Dunaliella salina to macronutrient deprivation. PLoS One 11:1-19

Machu L, Misurcova L, Ambrozova JV, Orsavova J, Mlcek J, Sochor J, Jurikova T (2015) Phenolic content and antioxidant capacity in algal food products. Molecules 20:1118-1133

Martina VR, Vojtech K (2015) A comparison of Biuret, Lowry and Brad ford methods for measuring the egg's protein. Mendel Net 394-398.

Michalak A (2006) Phenolic compounds and their antioxidant activity in plants growing under heavy Metal Stress. Polish J Environ Stud 15:523-530

Mohsenpour SF, Richards B, Willoughby N (2012) Spectral conversion of light for enhanced microalgae growth rates and photosynthetic pigment production. Biores Technol 125:75-81

Muhaemin M, Soedharma D, Madduppa HH, Zamani NP (2017) Glutathione (GSH) production as protective adaptation against light regime radiation of Symbiodinium natural population. Indones $\mathbf{J}$ Mar Sci 22:121-125 
Neidhardt J, Benemann JR, Zhang L, Melis A (1998) Photosystem-II repair and chloroplast recovery from irradiance stress: Relationship between chronic photoinhibition, light-harvesting chlorophyll antenna size and photosynthetic productivity in Dunaliella salina (green algae). Photosynth Res 56:175-184

Nguyen A, Tran D, Ho M, Louime C, Tran H, Tran D (2016) High light stress regimen on Dunaliella salina strains for carotenoids induction. Integr Food Nutr Metab 3:347-350

Nimse SB, Pal D (2015) Free radicals, natural antioxidants, and their reaction mechanisms. RSC Adv 5:27986-28006

Ordog V, Stirk WA, Balint P, Aremu AO, Okem A, Lovasz C, Molnar Z, van Staden J (2016) Effect of temperature and nitrogen concentration on lipid productivity and fatty acid composition in three Chlorella strains. Algal Res 16:141-149

Orefice I, Chandrasekaran R, Smerilli A, Corato F, Caruso T, Casillo A, Corsaro MM, Piaz FD, Ruban AV, Brunet C (2016) Lightinduced changes in the photosynthetic physiology and biochemistry in the diatom Skeletonema marinoi. Algal Res 17:1-13

Park S, Polle JEW, Melis A, Lee TK, Jin E (2006) Up-regulation of photoprotection and PSII-repair gene expression by irradiance in the unicellular green alga Dunaliella salina. Mar Biotechnol 8:120-128

Radyuk MS, Domanskaya IN, Shcherbakov RA, Shalygo NV (2009) Effect of low above-zero temperature on the content of low-molecular antioxidants and activities of antioxidant enzymes in green barley leaves. Russ J Plant Physiol 56:175-180

Rahal A, Kumar A, Singh V, Yadav B, Tiwari R, Chakraborty S, Dhama K (2014) Oxidative stress, prooxidants, and antioxidants: the interplay. BioMed Res Int 2014:761264

Ras M, Steyer JP, Bernard O (2013) Temperature effect on microalgae: a crucial factor for outdoor production. Rev Environ Sci Biotechnol 12:153-164

Rivkin R (1989) Influence of irradiance and spectral quality on the carbon metabolism of phytoplankton I. Photosynthesis, chemical composition and growth. Mar Ecol Prog Ser 55:291-304

Robinson DH, Arrigo KR, Iturriaga R, Sullivan CW (1995) Microalgal light-harvesting in extreme low-light environments in Mcmurdo Sound, Antarctica. J Phycol 31:508-520

Salbitani G, Bottone C, Carfagna S (2017) Determination of Reduced and Total Glutathione Content in Extremophilic Microalga Galdieria phlegrea. Bio-Protocol 7

Sanchez-Saavedra M, del P, Voltolina D, (2006) The growth rate, biomass production and composition of Chaetoceros sp. grown with different light sources. Aquacult Eng 35:161-165

Schulze PSC, Pereira HGC, Santos TFC, Schueler L, Guerra R, Barreira LA, Perales JA, Varela JCS (2016) Effect of light quality supplied by light emitting diodes (LEDs) on growth and biochemical pro files of Nannochloropsis oculata and Tetraselmis chuii. Algal Res 16:387-398

Sen A (2012) Oxidative stress studies in plant tissue culture. In: ElMissiry MA (ed) Antioxidant enzyme. Intech Open Limited, London, pp 59-88

Shah K, Kumar RG, Verma S, Dubey RS (2001) Effect of cadmium on lipid peroxidation, superoxide anion generation and activities of antioxidant enzymes in growing rice seedlings. Plant Sci 161:1135-1144

Sharma P, Jha AB, Dubey RS, Pessarakli M (2012) Reactive oxygen species, oxidative damage, and antioxidative defense mechanism in plants under stressful conditions. J Bot 2012:1-26
Shu CH, Tsai CC, Liao WH, Chen KY, Huang HC (2012) Effects of light quality on the accumulation of oil in a mixed culture of Chlorella sp. and Saccharomyces cerevisiae. J Chem Technol Biotechnol 87:601-607

Singh P, Baranwal M, Reddy SM (2016) Antioxidant and cytotoxic activity of carotenes produced by Dunaliella salina under stress. Pharm Biol 54:2269-2275

Sukenik A, Bennett J, Mortain-Bertrand A, Falkowski PG (1990) Adaptation of the photosynthetic apparatus to irradiance in Dunaliella tertiolecta: a kinetic study. Plant Physiol 92:891-898

Takache H, Pruvost J, Marec H (2015) Investigation of light/dark cycles effects on the photosynthetic growth of Chlamydomonas reinhardtii in conditions representative of photobioreactor cultivation. Algal Res 8:192-204

Thompson PA, Guo M, Harrison PJ (1992) Effects of Variation in Temperature. I. on the Biochemical Composition of Eight Species of Marine Phytoplankton1. J Phycol 28:481-488

Tian J, Yu J (2009) Changes in ultrastructure and responses of antioxidant systems of algae (Dunaliella salina) during acclimation to enhanced ultraviolet-B radiation. J Photochem Photobiol 97:152-160

Wang Z, Xiao Y, Chen W, Tang K, Zhang L (2010) Increased vitamin $\mathrm{C}$ content accompanied by an enhanced recycling pathway confers oxidative stress tolerance in Arabidopsis. J Integr Plant Biol 52:400-409

Wu Z, Duangmanee P, Zhao P, Ma C (2016) The effects of light, temperature, and nutrition on growth and pigment accumulation of three Dunaliella salina strains isolated from saline soil. Jundishapur J Microbiol 9:1-9

$\mathrm{Xu}$ Y, Ibrahim IM, Harvey PJ (2016) The influence of photoperiod and light intensity on the growth and photosynthesis of Dunaliella salina (chlorophyta) CCAP 19/30. Plant Physiol Biochem 106:305-315

Yilancioglu K, Cokol M, Pastirmaci I, Erman B, Cetiner S (2014) Oxidative stress is a mediator for increased lipid accumulation in a newly isolated Dunaliella salina strain. PLoS ONE 9:e91957

Zervoudakis G, Salahas G, Rodi M (2015) Nitrogen nutrition effect on aeroponic basil (Ocimum basilicum L.) catalase and lipid peroxidation. Not Bot Hort Agrobot Cluj 43:561-567

Zhang M, Cao T, Ni L, Xie P, Li Z (2010) Carbon, nitrogen and antioxidant enzyme responses of Potamogeton crispus to both low light and high nutrient stresses. Environ Exp Bot 68:44-50

Zhang YK, Zhu DF, Zhang YP, Chen HZ, Xiang J, Lin XQ (2015) Low $\mathrm{pH}$-induced changes of antioxidant enzyme and ATPase activities in the roots of rice (Oryza sativa L.) seedlings. PLoS One 10:1-12

Zhu H, Li X, Zhai W, Liu Y, Gao Q, Liu J, Ren L, Chen H, Zhu Y (2017) Effects of low light on photosynthetic properties, antioxidant enzyme activity, and anthocyanin accumulation in purple pak-choi (Brassica campestris ssp. Chinensis Makino). PLoS One 12:1-17

Publisher's Note Springer Nature remains neutral with regard to jurisdictional claims in published maps and institutional affiliations. 